\title{
Measuring the Average Marginal Tax Rate from the Individual Income Tax
}

\section{Citation}

Barro, Robert J., and Chaipat Sahasakul. 1983. Measuring the average marginal tax rate from the individual income tax. Journal of Business 56(4): 419-452.

\section{Published Version}

doi:10.1086/296211

\section{Permanent link}

http://nrs.harvard.edu/urn-3:HUL.InstRepos:3451293

\section{Terms of Use}

This article was downloaded from Harvard University's DASH repository, and is made available under the terms and conditions applicable to Other Posted Material, as set forth at http:// nrs.harvard.edu/urn-3:HUL.InstRepos:dash.current.terms-of-use\#LAA

\section{Share Your Story}

The Harvard community has made this article openly available.

Please share how this access benefits you. Submit a story.

Accessibility 


\section{Measuring the Average Marginal Tax Rate from the Individual Income Tax}

In order to assess the economic effects of taxation, we have to know the applicable marginal tax rates for individuals or businesses. For example, marginal tax rates on income affect decisions to work, produce, save, and invest. However, the readily available data refer to totals of tax collections in various categories, such as individual income taxes, corporate profits taxes, and so on. From these figures, we can construct measures of average tax rates. But, especially in the case of the graduated rate federal individual income tax, these measures do not tell us directly the fraction of income that the "representative" person gets to keep at the margin. Therefore, average tax rates may not provide an adequate basis for determining the allocative effects of taxation.

There have been some attempts-notably Joines (1981) and Seater (1982) - to use more detailed data to compute average marginal tax rates. Basically, for the federal individual income tax, they look across classes of adjusted gross income from the IRS data to see how taxes paid

\footnotetext{
* This research was supported by the National Science Foundation. We have benefited from comments by Gary Becker, Merton Miller, Sherwin Rosen, Larry Summers, and from discussion in the Workshop in Applications of Economics at the University of Chicago. We also appreciate the income-tax data that were provided by Charles Hicks.
}

(Journal of Business, 1983, vol. 56, no. 4)

(C) 1983 by The University of Chicago. All rights reserved. 0021-9398/83/5604-0001\$01.50
The economic effects of taxation depend on the configuration of marginal tax rates. We consider here the appropriate measure of a marginal tax rate for the federal individual income tax, which has a graduated rate structure and allows for numerous legal and illegal deductions from total income. Our conclusion is that the explicit marginal rate from the tax schedule is the right concept for many purposes. Hence, we construct appropriately weighted averages of these marginal tax rates for 1916-80. When weighted by adjusted gross income, the arithmetic average of marginal tax rates is $5 \%$ in $1920,2 \%$ in $1930,6 \%$ in $1940,20 \%$ in $1950,23 \%$ in 1960 , $24 \%$ in 1970 , and $30 \%$ in 1980 . 
per return vary with income per return. They then use the ratio of the change in taxes per return to the change in income per return to calculate marginal tax rates. Generally - as Joines and Seater argue is appropriate-this concept of a marginal tax rate is substantially smaller than the explicit rate from the tax schedule. But, as we discuss later, there are problems in interpreting their concept of a marginal tax rate in terms of the underlying substitution effects on individuals' choices. In fact, we argue that the explicit rate from the schedule is the right concept for many purposes. ${ }^{1}$

In the present paper we focus on the federal individual income tax. This category is interesting for several reasons. First, it is large-46\% of federal and $30 \%$ of total government revenues in 1980 . Second, the appropriate disaggregated data are available. Third, because of the graduated rate structure, the differences between marginal and average tax rates are likely to be important. However, a full measure of marginal tax rates would incorporate other levies, some of which are based on property or expenditures rather than on income. We do plan to include soon the social security tax ${ }^{2}$ which constitutes $26 \%$ of federal and $17 \%$ of total government revenues in 1980 . We may also consider other types of taxes, but even the full array of these would not be sufficient. That is because a full concept of a marginal tax rate encompasses also the transfers that people lose when they earn additional income. Thus far, we have no plans to tackle this issue.

\section{Theoretical Considerations}

We set up a simple model to deal with the following question: What is the appropriate concept of a marginal tax rate in the context of an income tax that, first, has a graduated rate structure and, second, allows for numerous legal and illegal deductions in the calculation of

1. Protopapadakis (1982) also uses the Joines-Seater approach to calculate average marginal tax rates for capital gain income. Earlier, Wright (1969) used the explicit rates from the tax schedule to calculate average marginal tax rates for interest and dividends over the period 1913-58. Except for his weighting by amounts of interest and dividend income, Wright's approach seems to accord with the one that we emphasize in this paper.

2. The important considerations are, first, distinguishing the self-employed from employees; second, allowing for the tax deductibility of employer contributions; and, third, ascertaining the fraction of persons (and their incomes) whose earnings exceed the ceiling amount. Joines (1981, p. 199) estimates the last element from the distribution of labor income per return from the IRS data. But this procedure is unsatisfactory, at least for families with more than one income earner. However, the appropriate data are available directly from the Social Security Administration. A more difficult issue concerns the extra benefits that people get when they "contribute" more to social security. The marginal benefit should be subtracted from the payments to compute a net marginal tax rate. But these calculations-which depend on anticipated benefit schedules-may be difficult. Some preliminary results appear in Gordon (1982). 
taxable income $?^{3}$ In particular, what is the relation among the various substitution effects on people's choices, the explicit tax rates from the tax schedule, the marginal association between taxes and total income (which is the Joines-Seater concept of a marginal tax rate), and the average tax rates?

Consider a family that receives market income, $Y$. This income comes partly from working the amount $L$ at the wage $w$ and partly from nonlabor income, $I$. Hence, total market income is

$$
Y=I+w L .
$$

Taxes depend on taxable income, $Y^{T}=Y-D$, where $D$ is a broad concept of deductions. This concept includes explicit deductions from the tax law (which are either a standard deduction or the itemized amounts for other taxes, interest, etc.), plus personal exemptions, plus unreported income, plus any excess allowances for business and moving expenses, plus the preferential treatment of deferred income and (real) capital gains, and so on.

The relation of taxes to taxable income comes from the law, which specifies the tax function,

$$
T=T\left(Y^{T}\right)
$$

where we assume that the marginal tax rate from the schedule, $T^{\prime}$, is nonnegative and nondecreasing-that is, $T^{\prime} \geqslant 0$ and $T^{\prime \prime} \geqslant 0$ (a "progressive" tax). We assume also that $T=0$ for $Y^{T} \leqslant 0 .^{4}$

We suppose that deductions-in our broad sense-depend first on the resources, $X$, that people devote to generating deductions, and second on the quantity of a family's consumption that the tax law treats favorably. In the United States this category, which we call $C^{2}$, includes owner-occupied housing, charity, various activities of state and local governments (since state and local taxes are deductible from federal taxable incomes), etc.

We write the function for deductions in the form

$$
D=f(X)+\alpha C^{2} \text {. }
$$

The first part of the function, $f(X)$, satisfies the properties $f^{\prime}>0, f^{\prime \prime}<$ 0 , and $f(0)>0$. Hence, someone who expends no effort generates the positive deduction, $f(0)$. More resources spent on tax avoidance, $X$, generate more deductions, but at a decreasing rate. ${ }^{5}$ We can also think

3. For a sketch of a related model, see Heckman (1983).

4. Since 1975, the earned-income credit makes $T^{\prime}<0$ (and $T<0$ ) for the federal individual income tax over some range of incomes. We neglect this element. Some other credits can effectively be combined with deductions in our subsequent formulation.

5. The function $f(X)$ would not be concave throughout if there were setup costs associated with producing deductions. At the low end of incomes there is nonconcavity because of the standard deduction, which is an effort-free alternative to itemized deductions. 
of the function $f(X)$ as incorporating the goods equivalent of any penalties for tax cheating, as well as the probability of being caught. Finally, we note that for some occupations, such as self-employment, the ease of concealing income and taking excessive business expenses implies that deductions, $f(X)$, are large for a small amount of effort.

The second term in equation (3), $\alpha C^{2}$, describes the effects of favored consumption. We treat $\alpha$ as a positive fraction, since-except for some limitations on the amounts of charitable contributions-there do not seem to be important sources of diminishing effects of favored consumption on deductions. (Business expenses could be entered explicitly as another source of deductions in eq. [3] - see n. 7 below.)

For some of our results, it matters that income-either total or taxable-not appear in the function that generates deductions, $f(X)$. One way income might enter is through the standard deduction, which depends on adjusted gross income in some years. But this provision turns out to be quantitatively unimportant for most purposes, because the standard deduction varies with income only over a limited range at the low end of incomes. For example, for 1944-63, the standard deduction is $10 \%$ of adjusted gross income, but only until the deduction reaches $\$ 1,000$. (Currently the standard deviation does not depend on income.) In any case, we neglect these features of the standard deduction in our analysis.

Another possibility is that the IRS's examination effort varies with a family's adjusted gross income, as well as with the claimed amounts of deductions. (It might depend also on occupation and other characteristics.) Then, depending on the IRS's procedure, someone with more adjusted gross income would find it either easier or harder to generate a given amount of deductions. That is, some measure of income would appear in the function $f(X)$. In fact, our subsequent analysis can be used to design an optimal pattern of enforcement by the IRS, which would include a possible dependence of the IRS's effort on someone's income. Although it would be interesting to explore this idea, we have not yet done so.

Finally, income might matter because of some limitations on categories of itemized deductions. For contributions, more income means more potential deductions. However, for medical expenses and now for casualty losses an increase in income means that fewer deductions can be claimed. Also, there are limitations on the amounts of interest expense that relate to "investment purposes." Here, an increase in someone's income from capital can increase these allowable deductions. Miller and Scholes (1978) stress this point.

In any case, the present analysis does not incorporate any direct effects of income in the function that generates deductions. Later on, we note the consequences of including income in this function.

Total income goes either to ordinary consumption, $C^{1}$, favored con- 
sumption, $C^{2}$, taxes, $T$, or tax avoidance, $X$. For expository purposes, we do not consider any saving. Hence, the family's budget constraint is 6

$$
Y=C^{1}+C^{2}+T+X .
$$

The family's utility depends positively on the two types of consumption and negatively on market work, $L$-that is,

$$
U=U\left(C^{1}, C^{2}, L\right)
$$

where the partial derivatives are $U_{1}, U_{2}>0$, and $U_{3}<0$. Families maximize utility, subject to the budget constraint from equation (4), the definition of total market income from equation (1), and the determination of taxes from equations (2) and (3). The resulting first-order conditions can be written as follows: ${ }^{7}$

$$
\begin{gathered}
f^{\prime}=1 / T^{\prime}, \\
-\frac{\partial U / \partial L}{\partial U / \partial C^{1}}=w\left(1-T^{\prime}\right), \\
-\frac{\partial U / \partial L}{\partial U / \partial C^{2}}=w\left(1-T^{\prime}\right) /\left(1-\alpha T^{\prime}\right) .
\end{gathered}
$$

Equation (6) determines the amount of resources, $X$, that people put into tax avoidance. At the margin, the gain from applying an extra unit of resources is the extra deductions, $f^{\prime}$, multiplied by the marginal tax rate from the schedule, $T^{\prime}$. Hence, people go to the point where the marginal gain, $f^{\prime} T^{\prime}$, equals the marginal cost, 1 . It follows that people with a higher marginal tax rate, $T^{\prime}$ - which will typically be those with higher total incomes-go to a lower value of $f^{\prime}$. Correspondingly, they spend more resources, $X$, on avoidance, and end up with more deductions, $D$.

Equation (7) says that the utility rate of substitution between ordinary consumption, $C^{1}$, and "leisure" equals the after-tax wage rate, where the adjustment for taxes uses the marginal rate from the tax schedule, $T^{\prime}$. Therefore, although people use resources and favored consumption to reduce their taxes, it is still the explicit marginal tax rate from the schedule that affects the allocation between ordinary consumption and leisure. That is because, at the margin, people have

6. We do not allow for changes in the relative prices of $C^{1}, C^{2}$, or $X$. Essentially we think of the various goods as perfect substitutes on the supply side.

7. As an alternative, we could write total income as the output of the production function, $Y=F(L, B)$, where $B$ is "business expenses," which could include the costs of moving. These business expenses then appear also in the function that generates deductions. In this formulation the marginal product of labor replaces the wage, $w$, in eqq. (7) and $(8)$. We also get the optimization condition for business expenses, $(\partial F / \partial B)\left(1-T^{\prime}\right)=$ $1-T^{\prime} \cdot(\partial D / \partial B)$, where $\partial D / \partial B$ is the marginal effect of business expenses on deductions. If $\partial D / \partial B=1$, then $\partial F / \partial B=1$ applies. 
the option to work an extra unit, earn $w$ on this amount, retain $w(1-$ $T^{\prime}$ ) as additional disposable income (since $X$ and $C^{2}$ do not shift at this margin), and spend the funds on $C^{18}{ }^{8}$

On the other hand, when choosing favored consumption, $C^{2}$, households consider the marginal effect, $\alpha$, on deductions. Therefore, in equation (8), the utility rate of substitution between favored consumption and leisure equals a different measure of the after-tax wage. The pertinent marginal tax rate here is $T^{\prime}(1-\alpha) /\left(1-\alpha T^{\prime}\right)$, which is below $T^{\prime}$ since $0<\alpha<1$ applies. (Viewed alternatively, the utility rate of substitution between $C^{1}$ and $C^{2}$ equals $1-\alpha T^{\prime}$ because of the preferential tax treatment for $C^{2}$.)

\section{Average Tax Rates and Deductions}

For some purposes, we would like to know how taxes vary crosssectionally with total income, $Y$. We can think of the variations in $Y$ as generated from underlying differences in either nonlabor income, $I$, or in the wage rate, $w$. Then we have

$$
\begin{aligned}
d T / d Y & =T^{\prime}(1-d D / d Y)=T^{\prime}\left(1-f^{\prime} \cdot d X / d Y-\alpha \cdot d C^{2} / d Y\right) \\
& =T^{\prime}\left(1-\alpha \cdot d C^{2} / d Y\right)-d X / d Y .
\end{aligned}
$$

Therefore, the marginal relation of taxes to income, $d T / d Y$, is below the explicit marginal tax rate, $T^{\prime}$, because of the positive relation between income and deductions, $d D / d Y$. This last term is positive, first, because more income means more effort spent at tax avoidance-that is, $d X / d Y>0$-and, second, because more income means more favored consumption-that is, $d C^{2} / d Y>0$. We also find that $0<d D /$ $d Y<1$ and hence that $0<d T / d Y<T^{\prime}$. (All of these results follow unambiguously as long as $0<d C^{2} / d Y<1$ holds.) Finally, we get the last expression in equation (9) by substituting the condition, $f^{\prime}=1 / T^{\prime}$, from equation (6).

Consider how the average tax rate, $T / Y$, changes with total income, $Y$. Since taxes are zero until total income reaches some positive amount (because some deductions accrue with zero effort), and since the marginal tax rate, $T^{\prime}$, rises with taxable income, the average tax rate tends also to increase with total income. In order for this possibly not to hold throughout, we need a range of income where the term $d T /$ $d Y$ declines with $Y$. But it is clear from equation (9) that this cannot happen if the marginal relation of deductions to income, $d D / d Y$, is a positive constant. Rather, we need a range of strong positive effects of income on $d D / d Y$ such that the ratio of deductions to income, $D / Y$, can

8. Here the results change if income has a direct effect on deductions (for reasons that we mentioned before). If this marginal effect on deductions is positive (negative), then the effective marginal tax rate is below (above) $T^{\prime}$. 
increase with income over some interval. But, the diminishing returns to tax avoidance-that is, $f^{\prime \prime}<0$-works against this. If we neglect the role of favored consumption, $C^{2}$, and look only at the response of the effort for tax avoidance, $X$, then we tend to get a diminishing effect of income on $d D / d Y .{ }^{9}$ Hence, $d T / d Y$-and, moreover, the average tax rate, $T / Y$-tend to increase with total income, $Y .^{10}$

There seem to be two main possibilities for reversing this result. First, there may be ranges where setup costs for tax avoidance are important, so that the concavity of the $f$-function does not hold throughout. Then, there may be regions where $D / Y$ rises with income, so that $T / Y$ may decline. Second, the response of deductions, $d D / d Y$, depends also on how favored consumption, $C^{2}$, reacts to higher income. If the favored items are luxury goods or if the demand for these goods becomes increasingly responsive (positively) to higher marginal tax rates, then the term $d D / d Y$ may rise with total income. Then, the response of taxes, $d T / d Y$, conceivably would decline over some range (see n. 10 above).

Overall, it is not easy theoretically to generate positive effects of total income on $d D / d Y$. (Empirically, if we measure $Y$ by adjusted gross income, then $d D / d Y$ appears to be roughly constant as income varies cross-sectionally-see below.) Hence, the term $d T / d Y$-and, moreover, the average tax rate, $T / Y$-are likely to rise with total income.

We focus empirically on measuring the marginal tax rate from the tax schedule, $T^{\prime}$. This rate governs the substitution between ordinary goods, $C^{1}$, and work. But, as mentioned before, some others-for example, Joines (1981) and Seater (1982)-attempt to calculate the expression $d T / d Y$. (Empirically, they measure $Y$ by adjusted gross income, rather than by total income, which is unobservable.) Therefore, this alternative procedure includes the response of deductions, $d D / d Y$, in the measure of a "marginal tax rate." Clearly, this expression understates the marginal tax rate, $T^{\prime}$, which applies to the substitution between ordinary goods and work. But we may also be interested in the lower marginal tax rate, $T^{\prime}(1-\alpha) /\left(1-\alpha T^{\prime}\right)$, which applies to the

9. Neglecting terms that involve third derivatives and ignoring changes in $C^{2}$, we can show from a good deal of algebra that

$$
(d / d Y)(d D / d Y)=(+) \cdot \frac{-3 f^{\prime}\left(f^{\prime \prime}\right)^{2}\left(T^{\prime \prime}\right)^{2}}{\left(f^{\prime}\right)^{2} T^{\prime \prime}-T^{\prime} f^{\prime \prime}}<0 .
$$

The terms involving third derivatives reinforce this result if $T^{\prime \prime \prime}<0$ and $f^{\prime \prime \prime}<0$. The data suggest that $T^{\prime \prime \prime} \simeq 0$ is satisfactory over a substantial range of income, with $T^{\prime \prime \prime}<0$ applying in the upper tail. If $f^{\prime \prime} \rightarrow 0$ and $f^{\prime \prime} \rightarrow 0$ as $X \rightarrow \infty$, then we must have a range where $f^{\prime \prime \prime}>0$ applies.

10. Note that $d T / d Y=T^{\prime}(1-d D / d Y)$. Hence it follows that $(d / d Y)(d T / d Y)=-T^{\prime}(d /$ $d Y)(d D / d Y)+T^{\prime \prime}(1-d D / d Y)^{2}$. Therefore, since $T^{\prime \prime}>0$, we know that $(d / d Y)(d T / d Y)>0$ if $(d / d Y)(d D / d Y)<0$. 
margin between favored goods, $C^{2}$, and work. Under a very special condition, the Joines-Seater construct, $d T / d Y$, approximates an appropriate weighted average of the two marginal tax rates, $T^{\prime}$ and $T^{\prime}(1-\alpha) /$ $\left(1-\alpha T^{\prime}\right)$. Basically, this happens if the effort for tax avoidance is unimportant-in the sense that $d X / d Y \simeq 0$-and if favored consumption is roughly unit elastic in total income. ${ }^{11}$ (Even here we can get into trouble when we use adjusted gross income as a proxy for total income.) Generally, we cannot directly use a measure of $d T / d Y$ to represent the underlying substitution effects from taxation.

Our results, which focus on the rate from the tax schedule, $T^{\prime}$, provide estimates for one of the interesting marginal tax rates in the theory. But at present we have not figured out how to measure the other marginal tax rate, $T^{\prime}(1-\alpha) /\left(1-\alpha T^{\prime}\right)$. Fundamentally, this is because we lack observable measures for avoidance effort, $X$, favored consumption, $C^{2}$, and total income, $Y$. Conceivably we may be able to go further here by constructing some useful proxies. For example, itemized deductions give some information about favored consumption. Also, the expenditures on accountants may tell us something about the effort for tax avoidance, $X$.

\section{Weighting}

Suppose that we know each family's marginal income tax rate, $T_{i}^{\prime}$, at a particular date. We want to construct an aggregate index-or average marginal tax rate- $\bar{T}^{\prime}$, which can be used to understand some aggregate behavior. As is usual, we cannot construct a single index that works satisfactorily in all contexts. But there are some interesting special cases which suggest that it might be valuable to constuct some indices.

Assume first that the logarithm of each family's total consumption demand, $C_{i}$, depends linearly on the marginal tax rate, $T_{i}^{\prime}$ - that is, ${ }^{12}$

$$
\log \left(C_{i}\right)=a_{i}-b T_{i}^{\prime}
$$

(We can think alternatively of the supply of goods, $Y_{i}$, as depending on $T_{i}^{\prime}$.) Now, if everyone's slope coefficient, $b$, on $T_{i}^{\prime}$ in equation (10) is the same, then we can readily construct a useful measure of average marginal tax rates. This average is a linear combination of the $T_{i}^{\prime}$ with

11. The desired weighted combination of marginal tax rates is presumably $T^{\prime} \cdot C^{1} /\left(C^{1}\right.$ $\left.+C^{2}\right)+\left[\mathrm{T}^{\prime}(1-\alpha) /\left(1-\alpha T^{\prime}\right)\right] \cdot\left[C^{2} /\left(C^{1}+C^{2}\right)\right]$. The expression $d T / d Y$ equals this if $d X /$ $d Y=0$ and $d C^{2} / d Y=\left[C^{2} /\left(C^{1}+C^{2}\right)\right]\left[\left(1-T^{\prime}\right) /\left(1-\alpha T^{\prime}\right)\right]$.

12. Recall that we have abstracted from saving-hence, the effect of $T_{i}^{\prime}$ in eq. (10) reflects only the substitution between market goods and leisure. Possibly, individuals perceive their current marginal tax rates as permanent, so that the main intertemporal substitution effects do not arise. 
weights equal to $C_{i} / \bar{C}$, where $\bar{C}$ is aggregate consumption-that is,

$$
\bar{T}^{\prime}=\sum_{i}\left(C_{i} / \bar{C}\right) T_{i}^{\prime}
$$

Here the relation of aggregate consumption to the constructed average marginal tax rate will reveal the common slope coefficient. Specifically, the proportional response of $\bar{C}$ to $\bar{T}^{\prime}$ approximates the underlying coefficient, $b$. (The result turns out to be approximate because our measures for changes in $\bar{T}^{\prime}$ pick up some effects from shifts in weights.) Empirically, we use shares of adjusted gross income to proxy for the weights by shares of consumption.

Alternatively, we might have that each family's consumption exhibits a constant elasticity of response to the fraction of income that they keep at the margin, $\left(1-T_{i}^{\prime}\right)$. This amounts to postulating a constant elasticity with respect to the after-tax wage. The form for consumption is then

$$
\log \left(C_{i}\right)=A_{i}+B \cdot \log \left(1-T_{i}^{\prime}\right)
$$

Now, if the elasticity, $B$, is the same for all, then the appropriate index is defined implicitly by

$$
\log \left(1-\bar{T}^{\prime}\right)=\sum_{i}\left(C_{i} / \bar{C}\right) \cdot \log \left(1-T_{i}^{\prime}\right)
$$

If we construct the average marginal tax rate from equation (13), then the elasticity of aggregate consumption, $\bar{C}$, to the term $\left(1-\bar{T}^{\prime}\right)$ approximates the common elasticity, $B$. Here the index amounts to a geometric weighted average of the $\left(1-T_{i}^{\prime}\right)$. Because $\log \left(1-T_{i}^{\prime}\right)$ is a convex function of $T_{i}^{\prime}$, the averages computed from equation (13) exceed those found from equation (11). But empirically, these two types of indices for average marginal tax rates do not differ greatly.

For some purposes-for example, when measuring employment or unemployment-we count numbers of persons rather than amounts of consumption or income. Then, in the formulas from equations (11) or (13), we can think of the weight, $C_{i} / \bar{C}$, as reflecting the $i$ th family's share of total workers or persons rather than of consumption or income. Hence we would be more interested in person-weighted average marginal tax rates than in income-weighted numbers. Operationally, we can construct indices of average marginal tax rates where the individual rates are weighted by numbers of returns rather than by adjusted gross income. The indices weighted by numbers of returns are typically much lower than those weighted by adjusted gross income. 


\section{An Overview of the Data}

Our estimates for marginal tax rates refer to the federal individual income tax, as reported for each year for 1916-80 in the Internal Revenue Service's Statistics of Income. Unfortunately, the data are not reported in an entirely consistent manner over time. (This reflects either progress or shifting tastes.) Therefore, we combine the sources into groups by years as indicated below.

1961-77, 1979-80

There are tables classified by the highest marginal tax rates that apply to each return. (For 1980, the tables are in Statistics of Income Bulletin, December 1982.) These tables show the numbers of returns and the adjusted gross and taxable income that apply in each class. From these tables we can compute average marginal tax rates, using either shares of adjusted gross income or shares of numbers of returns as weights. However, we have to make some approximations in order to take account of the maximum tax rate on earned income (60\% in 1971, 50\% for 1972-80). Basically, for those who pay the maximum tax, we treat their marginal tax rate as $50 \%$ (60\% in 1971) for all types of income. ${ }^{13}$ However, the overall impact of the adjustment for the maximum tax is not too large-for example, in 1979 only about $4 \%$ of the aggregate of adjusted gross income applies to returns that use the 50\% maximum rate on earned income. ${ }^{14}$

1954-60

There are tables classified by ranges of taxable income per return and by filing status (married/filing jointly, single, etc.). Using the tax schedule for each filing status, we can compute the associated marginal tax rate. ${ }^{15}$ However, these tables do not provide information about ad-

13. The marginal tax rate on earned income can exceed $50 \%$ because the tax law requires people to allocate itemized deductions to earned and unearned income in proportion to the amounts of earned and unearned income. Thus, more earned income means less deductions allocated to unearned income, for which the marginal tax rate could exceed $50 \%$. Also, an extra dollar of earned income may push the marginal dollar of unearned income into a higher tax bracket. (For a discussion of these matters, see Sunley 1974.) Quantitatively, these considerations turn out to be unimportant for our calculations.

14. Recall that we neglect the earned income credit, which applies since 1975 for taxpayers who have a dependent child. For 1981, the credit rises by $10 \%$ of earned income up to a total earned income of $\$ 5,000$. Hence, the marginal tax rate is $-10 \%$ over this range. (People with negative taxes receive money from the government.) Then, the credit is constant until earned income equals $\$ 6,000$ but falls by $121 / 2 \%$ of earned income up to a total of $\$ 10,000$. In this range someone's marginal tax rate is $121 / 2 \%$ plus the explicit rate from the tax schedule. (For incomes above $\$ 10,000$, the credit stays at zero.) The amount of earned income credit depends also (negatively) on the quantity of unearned income.

15. We also make an adjustment for alternative tax computations. 
justed gross income. So, we calculate here only the average marginal tax rates when weighted by numbers of returns.

\section{6-43}

The tables are classified by net income, which is roughly taxable income plus exemptions for self, spouse, and other dependents. The taxrate schedules do not depend on marital status for these years. Within each class of net income, we make the approximation that everyone has the same taxable income-that is, we neglect variations in the ratio of exemptions to net income. For the purposes of calculating average marginal tax rates, this approximation is probably satisfactory. (The true dispersion in exemptions would not be too large and the marginal tax rates would be roughly linear, within each class, in taxable income.) Then, we can calculate marginal tax rates for each class of net income. We also have the data to weight these figures by numbers of returns and by total income, which corresponds roughly to adjusted gross income plus business expenses of individuals. This weighting by total income approximates that by adjusted gross income for the later years. ${ }^{16}$

\section{4-78}

We have tables classified by ranges of adjusted gross income per return and by filing status. The tables indicate for each class the amounts of taxable income and tax liabilities. We can compute marginal tax rates if we assume that each taxpayer in a given class has the same taxable income. More generally, our averages will be acceptable if the dispersion of marginal tax rates within a class is roughly linear in taxable income. In any event, we use these computations only to fill in the missing years from the other tables. These are 1944-60 and 1978 for the indices weighted by adjusted gross income and 1944-53 and 1978 for those weighted by numbers of returns. We fill in the missing data based on the relation of the different series over the overlapping years. The high correlation during the overlap suggests that this procedure is satisfactory.

16. There are interesting problems for 1942 and 1943, which involve the introduction of tax withholding with the legislation of January 1943. In order to avoid the payment of 2 years' worth of taxes in 1943, the government forgave roughly $75 \%$ of the tax liability for the year-either 1942 or 1943 - for which an individual's computed liability was smaller. Thus, someone's effective marginal tax rate for either 1942 or 1943 was only about $25 \%$ of the explicit rate. For most people, this would be 1942 . However, although the possibility of tax forgiveness was discussed before January 1943, we cannot say how much this provision was foreseen when people earned their incomes in 1942. In any event, our calculations for 1942 and 1943 use the explicit tax rate schedules, which disregard the effects of tax forgiveness. 


\section{Nonfilers and Unreported Income}

The IRS data that we use refer to filed returns and to amounts included in adjusted gross income. But conceptually our theory allows for gaps between a family's total income and the reported amount of adjusted gross income. Some of these differences are legal, such as the exclusion from adjusted gross income of nontaxable transfer payments, fringe benefits, some contributions to pension plans, and parts of the income from interest or capital gains. Other exclusions are illegal, reflecting especially the unreported income from the underground economy. However, the various exclusions from adjusted gross income do not disturb the conclusion that the explicit marginal tax rate from the schedule is the substitution variable that we wish to measure for each family. If we could, we would change the weighting pattern from shares of adjusted gross income to shares of a broader concept of income. But if each family filed an income tax return, we would not want to make an overall adjustment to account for the gap between the aggregates of adjusted gross and total income.

On the other hand, the data pick up only filed returns. Hence, we would like to include the nonfilers as families (and incomes) that face a zero marginal tax rate. Therefore, we need estimates for each year of the numbers of families (and their incomes) who do not file tax returns.

Over the period from 1949 to 1980 , the ratio of numbers of returns filed to the Census Bureau's estimate for the total number of households changes very little. Specifically, as shown in table 1, the ratio is 1.23 in 1949 and 1.18 in 1980 , with a range from 1.14 to 1.25 for the intervening years. (The ratio can exceed one because some households file more than one return and because the census's definition of a household does not coincide with the IRS's concept of a filing unit.) Therefore, we assume as an approximation that the fraction of families that do not file a return has not changed since 1949. However, since we do not know the value of this fraction, we make no adjustment during this period to account for nonfilers. This procedure will be satisfactory if nearly all families file a tax return, as is suggested by the high ratio of filed returns to numbers of households. But, to the extent that we miss some nonfilers, our tax rates will be too high by roughly a constant proportion.

Some recent research has suggested that the size of the underground economy increased dramatically during the 1970s. See O'Neill (1982) for a discussion and criticism of this work. Given this background, it is noteworthy that the ratio of numbers of returns to numbers of households changes little in recent years. If there had been a major increase in the importance of the underground economy, then we would have expected to see a decline in this ratio. However, the ratio would be sensitive only to variations in the numbers of families whose full-time 
TABLE 1 Ratios: Numbers of Returns to Numbers of Households and Adjusted Gross Income to Personal Income

\begin{tabular}{|c|c|c|c|c|c|}
\hline & $\begin{array}{l}\text { No. Returns } \div \\
\text { No. Households }\end{array}$ & $\begin{array}{l}\text { Adjusted } \\
\text { Gross } \\
\text { Income } \div \\
\text { Personal } \\
\text { Income }\end{array}$ & & $\begin{array}{l}\text { No. Returns } \div \\
\text { No. Households }\end{array}$ & $\begin{array}{l}\text { Adjusted } \\
\text { Gross } \\
\text { Income } \div \\
\text { Personal } \\
\text { Income }\end{array}$ \\
\hline 1916 & .02 & .21 & 1950 & 1.22 & .79 \\
\hline 1917 & .15 & .24 & 1951 & 1.24 & .80 \\
\hline 1918 & .19 & .28 & 1952 & 1.24 & .80 \\
\hline 1919 & .22 & .33 & 1953 & 1.25 & .80 \\
\hline 1920 & .30 & .36 & 1954 & 1.20 & .79 \\
\hline 1921 & .26 & .41 & 1955 & 1.21 & .80 \\
\hline 1922 & .26 & .41 & 1956 & 1.20 & .81 \\
\hline 1923 & .29 & .42 & 1957 & 1.20 & .80 \\
\hline 1924 & .27 & .42 & 1958 & 1.16 & .78 \\
\hline 1925 & .15 & .33 & 1959 & 1.16 & .80 \\
\hline 1926 & .15 & .32 & 1960 & 1.15 & .79 \\
\hline 1927 & .14 & .34 & 1961 & 1.14 & .79 \\
\hline 1928 & .14 & .37 & 1962 & 1.14 & .79 \\
\hline 1929 & .14 & .36 & 1963 & 1.15 & .79 \\
\hline 1930 & .13 & .31 & 1964 & 1.16 & .80 \\
\hline 1931 & .11 & .28 & 1965 & 1.17 & .80 \\
\hline 1932 & .13 & .30 & 1966 & 1.20 & .80 \\
\hline 1933 & .13 & .30 & 1967 & 1.21 & .80 \\
\hline 1934 & .13 & .29 & 1968 & 1.21 & .81 \\
\hline 1935 & .15 & .29 & 1969 & 1.22 & .80 \\
\hline 1936 & .17 & .32 & 1970 & 1.17 & .78 \\
\hline 1937 & .19 & .32 & 1971 & 1.15 & .78 \\
\hline 1938 & .19 & .32 & 1972 & 1.16 & .79 \\
\hline 1939 & .22 & .36 & 1973 & 1.17 & .78 \\
\hline 1940 & .42 & .52 & 1974 & 1.18 & .78 \\
\hline 1941 & .72 & .67 & 1975 & 1.15 & .75 \\
\hline 1942 & 1.00 & .70 & 1976 & 1.15 & .76 \\
\hline 1943 & 1.19 & .71 & 1977 & 1.16 & .76 \\
\hline 1944 & 1.27 & .71 & 1978 & 1.17 & .76 \\
\hline 1945 & 1.33 & .71 & 1979 & 1.19 & .75 \\
\hline 1946 & 1.38 & .76 & 1980 & 1.18 & .75 \\
\hline 1947 & 1.41 & .79 & & & \\
\hline 1948 & 1.28 & .79 & & & \\
\hline 1949 & 1.23 & .78 & & & \\
\hline
\end{tabular}

SourCES.- Numbers of returns and adjusted gross income are from Statistics of Income, Individual Income Tax Returns for each year. Numbers of households are from Historical Statistics of the U.S., Colonial Times to 1970, p. 43, and Statistical Abstract, various years. Personal Income is from The National Income and Product Accounts of the U.S., 1929-76, and Economic Report of the President, 1982. Values for 1916-28 are estimated from nominal GNP, based on the ratio of personal income to GNP for 1929. 
market activities are in the underground sector. Most people who participate only on a part-time basis would presumably file a tax return.

The ratio of filed returns to numbers of households is only 0.15 in 1917 but then rises because of the tax law changes in World War I to reach 0.30 in 1920. After falling to a range of $0.11-0.15$ from 1925 to 1935 , the ratio rises to 0.22 in 1939. Then, the major increases in the coverage of the tax law during World War II raise the ratio dramatically to 1.33 by 1945 and 1.41 in 1947 .

Effective 1948, the tax law introduced a schedule for married persons filing jointly, which differed from the schedule for single persons. Because of the decreased tendency for married persons to file separately, the ratio of returns filed to the number of households (as well as the absolute number of returns) declines from 1947 to 1949.

For the period 1916-46, we multiply the number of households by the value 1.41 , which is the ratio of numbers of returns to households for 1947. Thus we obtain an estimate for the total number of potential filing units for each year, given the pre-1948 tax law, which did not have a separate schedule for joint returns. Here we assume that virtually all of the potential units filed in 1947. Then we use the numbers on potential filing units when we compute the weights in the formula for average marginal tax rates (when weighted by numbers of returns). Equivalently, we include the estimated number of nonfilers-the estimated number of potential filers less the actual number of returns-as units that face zero marginal tax rates.

Finally, as with the period 1949-80, we make no adjustments for 1947-48. That is, we assume that virtually all potential filing units actually filed returns in these years.

In order to compute the indices when weighted by income, we used an estimate for each year of the income-corresponding to the concept of adjusted gross income as reported to the IRS-that accrues to nonfilers. We derive this estimate from the ratio of aggregate adjusted gross income to aggregate personal income, which appears in table 1. Notice that this ratio does not change greatly from 1946 to 1980 . The range of variation is from 0.75 to 0.81 , with no clear trend. ${ }^{17}$ As an approximation, we make no adjustment for this period to account for the income of nonfilers.

Before 1946, we calculate the gap for each year between the ratio of adjusted gross to personal income and the mean value, 0.79 , which applies from 1946 to 1980 . Then we assume that this gap corresponds to the income-equivalent to adjusted gross income-for those families that do not file returns. That is, we estimate the total of adjusted gross

17. Note that personal income includes only a small amount of unreported income, which comes from estimates by the IRS. (For a discussion, see O'Neill [1982, pp. 2 ff.].) Therefore, we cannot use the ratio of adjusted gross to personal income in order to infer the behavior of unreported income. 
income for each year by multiplying aggregate personal income by 0.79. Then we use this figure when we compute the weights in the formula for average marginal tax rates (when weighted by amounts of adjusted gross income).

\section{Results for Average Marginal Tax Rates}

Table 2 shows our time series of average marginal tax rates for 191680. We present four sets of figures, depending on whether the weights are by adjusted gross income or numbers of returns, and on whether the arithmetic or geometric averaging applies. Notice that the last consideration makes only a small difference. However, the average marginal tax rates are much lower-by as much as 10 percentage points in recent years-if the weighting is by numbers of returns rather than by income. The series that appear in table 2 involve some piecing together of different types of underlying data, as mentioned before. We provide the details in the Appendix.

For most purposes, the time series weighted by income, rather than by numbers of returns, will be more interesting. Then, because it makes little quantitative difference and because the arithmetic procedure corresponds to usual index formulas, we focus our discussion now on the series shown in the first column of table 2 . This series weights by adjusted gross income and uses the arithmetic form of average. The top graph in figure 1 shows these values of average marginal tax rates for 1916-80. The highlights are as follows.

From a value of about $1 \%$ in 1916, the average marginal tax rate rises along with major increases in the tax rate schedule to a peak of $5 \%$ during World War I. Then, because of a series of rate reductions through 1929 and the declines in income for 1930-31, the marginal rate falls to a low point of less than $2 \%$ in 1931. Subsequently, the rate rises sharply to reach $5 \%$ by 1936 . Apparently, the tax rate increases between 1932 and 1936 reflect the Hoover-Roosevelt program for fighting the Depression. In particular, for 1931, the marginal tax rates in the schedule start at $11 / 2 \%$, then rise to a top rate of $25 \%$ for taxable incomes above $\$ 100,000$. But in 1936 the rate starts at $4 \%$, reaches $62 \%$ for taxable incomes above $\$ 100,000$, and hits a top rate of $79 \%$ for taxable incomes above $\$ 5$ million.

From a value below $6 \%$ in 1940 , the average marginal tax rate climbs to a peak of $26 \%$ during World War II. These changes reflect three main elements: first, reductions in the levels of income at which taxes are positive; second, increases in the regular tax rates from the schedule; and third, special levies for the war. Following World War II, the average marginal tax rate declines to a low point of $18 \%$ in $1948-49$.

After a peak of $25 \%$ during the Korean War, the average marginal tax rate moves from $22 \%$ in 1954 to $25 \%$ in 1963 . Then, the famous Ken- 
TABLE 2 Average Marginal Tax Rates, 1916-80

\begin{tabular}{|c|c|c|c|c|}
\hline \multirow[b]{2}{*}{ Year } & \multicolumn{2}{|c|}{$\begin{array}{c}\text { Weighted by } \\
\text { Adjusted Gross Income }\end{array}$} & \multicolumn{2}{|c|}{$\begin{array}{l}\text { Weighted by } \\
\text { Numbers of Returns }\end{array}$} \\
\hline & Arithmetic & Geometric & Arithmetic & Geometric \\
\hline 1916 & .012 & .013 & .0003 & .0003 \\
\hline 1917 & .037 & .044 & .002 & .002 \\
\hline 1918 & .054 & .069 & .007 & .008 \\
\hline 1919 & .052 & .066 & .006 & .007 \\
\hline 1920 & .046 & .056 & .008 & .008 \\
\hline 1921 & .042 & .051 & .005 & .005 \\
\hline 1922 & .046 & .055 & .005 & .005 \\
\hline 1923 & .033 & .037 & .004 & .004 \\
\hline 1924 & .035 & .040 & .003 & .003 \\
\hline 1925 & .030 & .032 & .002 & .002 \\
\hline 1926 & .028 & .031 & .002 & .002 \\
\hline 1927 & .032 & .035 & .002 & .002 \\
\hline 1928 & .041 & .044 & .002 & .002 \\
\hline 1929 & .035 & .038 & .001 & .001 \\
\hline 1930 & .023 & .025 & .001 & .001 \\
\hline 1931 & .017 & .018 & .001 & .001 \\
\hline 1932 & .029 & .035 & .002 & .002 \\
\hline 1933 & .031 & .037 & .002 & .002 \\
\hline 1934 & .034 & .040 & .004 & .004 \\
\hline 1935 & .038 & .044 & .004 & .004 \\
\hline 1936 & .052 & .065 & .006 & .006 \\
\hline 1937 & .046 & .057 & .006 & .006 \\
\hline 1938 & .034 & .042 & .004 & .004 \\
\hline 1939 & .038 & .046 & .004 & .005 \\
\hline 1940 & .056 & .070 & .008 & .009 \\
\hline 1941 & .113 & .132 & .037 & .039 \\
\hline 1942 & .192 & .221 & .106 & .112 \\
\hline 1943 & .209 & .248 & .183 & .191 \\
\hline 1944 & .252 & .278 & .195 & .201 \\
\hline 1945 & .257 & .285 & .195 & .201 \\
\hline 1946 & .226 & .250 & .141 & .147 \\
\hline 1947 & .226 & .247 & .153 & .158 \\
\hline 1948 & .180 & .193 & .121 & .125 \\
\hline 1949 & .175 & .187 & .119 & .123 \\
\hline 1950 & .196 & .212 & .131 & .135 \\
\hline 1951 & .231 & .250 & .164 & .170 \\
\hline 1952 & .251 & .268 & .181 & .188 \\
\hline 1953 & .249 & .264 & .183 & .190 \\
\hline 1954 & .222 & .237 & .159 & .165 \\
\hline 1955 & .228 & .244 & .164 & .169 \\
\hline 1956 & .232 & .247 & .167 & .173 \\
\hline 1957 & .232 & .246 & .169 & .174 \\
\hline 1958 & .229 & .243 & .167 & .172 \\
\hline 1959 & .236 & .251 & .172 & .177 \\
\hline 1960 & .234 & .248 & .172 & .177 \\
\hline 1961 & .240 & .254 & .174 & .180 \\
\hline 1962 & .244 & .257 & .177 & .182 \\
\hline 1963 & .247 & .260 & .179 & .185 \\
\hline 1964 & .221 & .230 & .156 & .161 \\
\hline
\end{tabular}


TABLE 2

(Continued)

\begin{tabular}{|c|c|c|c|c|}
\hline \multirow[b]{2}{*}{ Year } & \multicolumn{2}{|c|}{$\begin{array}{c}\text { Weighted by } \\
\text { Adjusted Gross Income }\end{array}$} & \multicolumn{2}{|c|}{$\begin{array}{c}\text { Weighted by } \\
\text { Numbers of Returns }\end{array}$} \\
\hline & Arithmetic & Geometric & Arithmetic & Geometric \\
\hline 1965 & .212 & .221 & .148 & .153 \\
\hline 1966 & .217 & .226 & .153 & .157 \\
\hline 1967 & .223 & .232 & .157 & .161 \\
\hline 1968 & .252 & .264 & .173 & .178 \\
\hline 1969 & .261 & .274 & .181 & .187 \\
\hline 1970 & .243 & .254 & .168 & .174 \\
\hline 1971 & .239 & .249 & .164 & .170 \\
\hline 1972 & .242 & .252 & .164 & .169 \\
\hline 1973 & .250 & .260 & .170 & .176 \\
\hline 1974 & .257 & .268 & .176 & .182 \\
\hline 1975 & .263 & .273 & .178 & .185 \\
\hline 1976 & .273 & .283 & .185 & .193 \\
\hline 1977 & .281 & .283 & .187 & .196 \\
\hline 1978 & .310 & .319 & .208 & .218 \\
\hline 1979 & .289 & .302 & .190 & .199 \\
\hline 1980 & .304 & .318 & .200 & .210 \\
\hline
\end{tabular}

Note.-We discuss in the text the procedure for weighting by adjusted gross income or by numbers of returns. The arithmetic indices have the form of eq. (11), while the geometric ones correspond to eq. (13). We use the tables from Statistics of Income, Individual Income Tax Returns for each year, as discussed in the text. The Appendix details the procedure for obtaining the figures in the middle periods (1944-60, 1978, when weighted by adjusted gross income; and 1944-53, 1978, when weighted by numbers of returns).

nedy-Johnson tax cuts reduce the rate to $21 \%$ in 1965 . Subsequently, the growth in nominal incomes and the Vietnam surcharge raise the rate to $25 \%-26 \%$ for $1968-69$. Then, following the removal of the surcharge, the effects of bracket creep increase the rate steadily from $24 \%$ in 1971 to $31 \%$ in 1978 . For 1979 the rate falls to $29 \%$, apparently because of a widening in the tax brackets, although there are no changes in the lowest and highest tax rates. But for 1980 the average marginal tax rate rises to $30 \%$.

The first column of table 3 and the lower curve in figure 1 show a simple measure of an average tax rate. This rate is the ratio of total federal individual income taxes to the aggregate of personal income. Because of the graduated rate structure of the tax law and the excess of personal over taxable income, we anticipate that this type of average tax rate would be below our measure of the average marginal tax rate. Also, while many changes in the tax law and in incomes would generate correlated movements in the two measures of tax rates, there are others-such as changes in deductibles versus changes in statutory tax rates-that would produce substantial divergences.

Empirically, the average tax rate is $30 \%-40 \%$ of our average marginal rate (37\% for $1916-80,41 \%$ for $1946-80$, and $39 \%$ for $1970-80$ ). But the bulk of the movements in the two series are parallel. For 1916- 


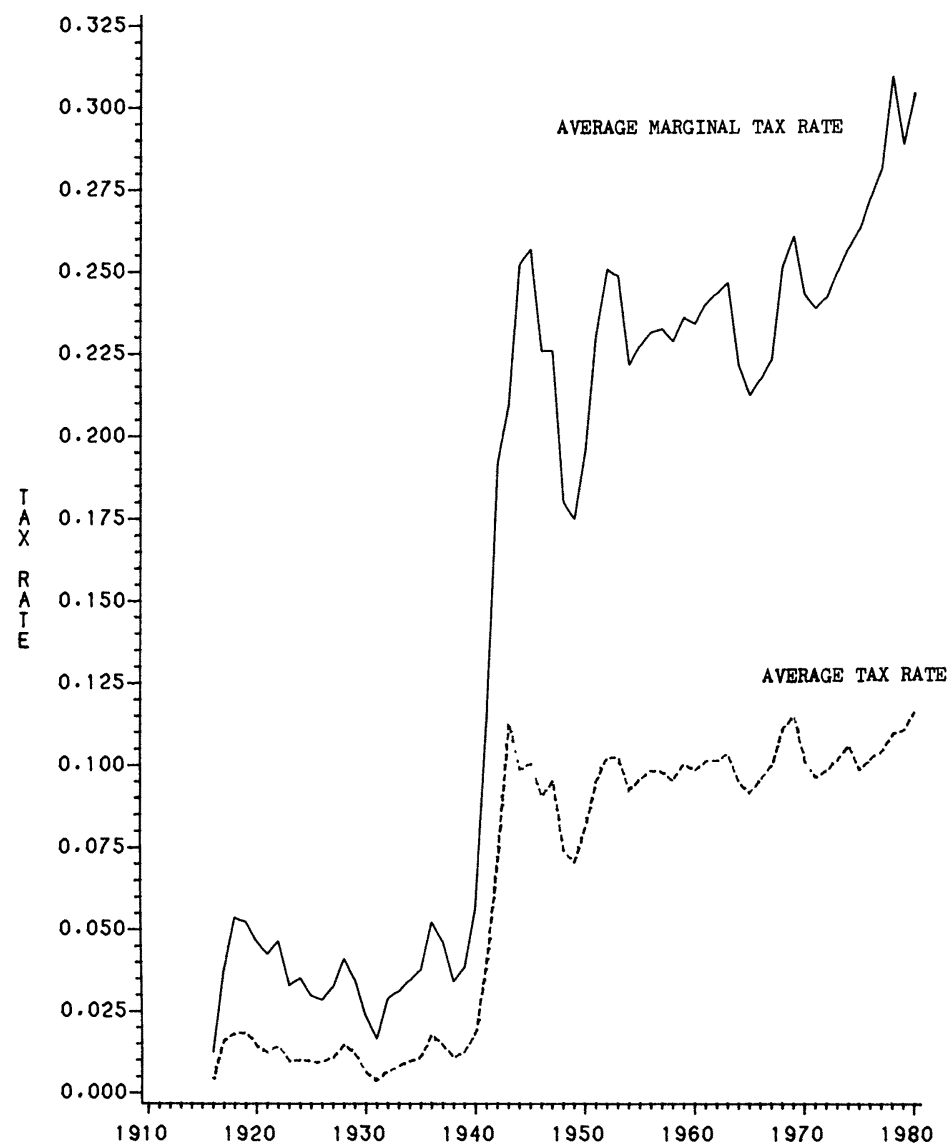

Fig. 1.-Average marginal tax rate and average tax rate. (Note: The average marginal tax rate is the arithmetic index, weighted by adjusted gross income, from table 2. The average tax rate appears in table 3.)

80 , the correlations between the two are .99 in levels but only .73 in first differences. For 1946-80, the comparable figures are .88 and .89 . Some notable differences between the series show up in recent years. For example, the average tax rates for 1974 and 1977 are nearly the same, but the average marginal rate for 1977 is 2.4 percentage points higher. Then, the average tax rate changes little from 1978 to 1979 , but the average marginal rate falls by about 2 percentage points. Overall, for 1970-80, the correlation of the average marginal tax rate with the average tax rate is .85 in levels but only .44 in first differences.

Table 3 shows also the average marginal tax rates that Joines (1981, table 9) calculates for 1929-75. (We use his series that applies to the federal income tax on labor income.) As noted earlier, Joines attempts to measure the marginal relation of taxes to income, $d T / d Y$. He carries 
TABLE 3 Other Estimates of Tax Rates

\begin{tabular}{|c|c|c|c|c|c|}
\hline Year & $\begin{array}{l}\text { Average } \\
\text { Tax Rate }\end{array}$ & $\begin{array}{c}d T / d Y \\
\text { (Joines) }\end{array}$ & Year & $\begin{array}{l}\text { Average } \\
\text { Tax Rate }\end{array}$ & $\begin{array}{c}d T / d Y \\
\text { (Joines) }\end{array}$ \\
\hline 1916 & .004 &.. & 1950 & .081 & .159 \\
\hline 1917 & .016 & . . . & 1951 & .095 & .186 \\
\hline 1918 & .018 &.. & 1952 & .102 & .190 \\
\hline 1919 & .018 & . . & 1953 & .102 & .188 \\
\hline 1920 & .014 & . . . & 1954 & .092 & .171 \\
\hline 1921 & .013 &.. & 1955 & .095 & .176 \\
\hline 1922 & .014 & . . . & 1956 & .098 & .177 \\
\hline 1923 & .010 & . . . & 1957 & .098 & .188 \\
\hline 1924 & .010 & . . . & 1958 & .095 & .182 \\
\hline 1925 & .010 &.. & 1959 & .100 & .190 \\
\hline 1926 & .009 &. & 1960 & .098 & .195 \\
\hline 1927 & .011 & . . . & 1961 & .101 & .194 \\
\hline 1928 & .015 &. & 1962 & .101 & .196 \\
\hline 1929 & .012 & .023 & 1963 & .103 & .198 \\
\hline 1930 & .006 & .018 & 1964 & .095 & .178 \\
\hline 1931 & .004 & .013 & 1965 & .092 & .182 \\
\hline 1932 & .007 & .020 & 1966 & .095 & .186 \\
\hline 1933 & .008 & .028 & 1967 & .100 & .189 \\
\hline 1934 & .010 & .031 & 1968 & .111 & .210 \\
\hline 1935 & .011 & .033 & 1969 & .115 & .218 \\
\hline 1936 & .018 & .047 & 1970 & .101 & .205 \\
\hline 1937 & .015 & .052 & 1971 & .096 & .186 \\
\hline 1938 & .011 & .046 & 1972 & .098 & .204 \\
\hline 1939 & .012 & .046 & 1973 & .102 & .219 \\
\hline 1940 & .018 & .082 & 1974 & .106 & .234 \\
\hline 1941 & .040 & .110 & 1975 & .098 & .237 \\
\hline 1942 & .072 & .174 & 1976 & .102 &.. \\
\hline 1943 & .113 & .194 & 1977 & .104 & . . . \\
\hline 1944 & .099 & .203 & 1978 & .109 & $\cdots$ \\
\hline 1945 & .100 & .208 & 1979 & .110 & \\
\hline 1946 & .090 & .183 & 1980 & .116 & . . . \\
\hline 1947 & .095 & .176 & & & \\
\hline 1948 & .074 & .142 & & & \\
\hline 1949 & .070 & .138 & & & \\
\hline
\end{tabular}

Note.-The average tax rate equals the ratio of total individual income taxes (after credits) to the aggregate of personal income. The data on taxes are from Statistics of Income, Individual Income Tax Returns for each year. For personal income, see the notes to table 1 . The values for $d T / d Y$ are from Joines (1981, table 9, the column labeled PTL).

this out by seeing how the tax paid per return changes with the adjusted gross income per return as we move from one class of adjusted gross income to the next. ${ }^{18}$ Thus, he incorporates both the effects of the marginal tax rate from the schedule, $T^{\prime}$, and the positive association of deductions per return with income per return. (Here, deductions refer to the difference between adjusted gross and taxable income. The gap

18. Joines's (1981) values also weight by the estimated fraction of total labor income in each income class, rather than by adjusted gross income. 
between adjusted gross and total income is not considered because of lack of data.)

Not surprisingly, Joines's values are below our measures of average marginal tax rates. For example, for $1970-75$ his figures average $86 \%$ of ours, while for $1946-75$ the percentage is $81 \%$. The correlations of Joines's values with ours for 1946-75 are .91 in levels and .88 in first differences. (Before 1946, the adjustment for nonfilers means that our series and Joines's are not directly comparable.)

Suppose now that we compare our average marginal tax rates (col. 1 of table 2) with the average tax rates and Joines's values, which appear in table 3. Clearly, in terms of the levels of the numbers, it makes a great deal of difference which series one uses. However, because of the correlation among the series, the choice may be less important for the purpose of time-series regression analysis. But there are substantial differences in the behavior of all three series over time. Until we employ these series for other purposes-for example, in explaining the behavior of aggregate output and employment-we cannot be sure how important these differences are.

\section{The Dispersion of Marginal Tax Rates}

We look now at the cross-sectional dispersion of marginal tax rates for the recent period, 1961-77, 1979-80. For these years, we have the tables that classify directly by the highest marginal tax rates. Figures 2-6 show the cumulative density functions for the marginal tax rates for some selected years, 1961, 1965, 1970, 1975, and 1980. In each case the upper curve applies to numbers of returns while the lower one refers to amounts of adjusted gross income. For example, for 1980, figure 6 indicates that $61 \%$ of the returns and $29 \%$ of the adjusted gross income are subject to marginal tax rates that are less than or equal to $22 \%$.

Table 4 shows for the period, 1961-77, 1979-80, the standard deviations, $\sigma$, of the marginal tax rates about their arithmetic means when weighted either by adjusted gross income or by numbers of returns. When weighted by numbers of returns, the standard deviation rises from .084 in 1967 to .125 in 1980 . However, when weighted by adjusted gross income, this pattern shows up only since 1973, where the increase is from .110 to .129 .

In some simple welfare analyses, the amount of distortion depends on the square of the tax rate. We can get a crude idea of the change over time in this measure of distortion by examining the changes in the mean value of the square of the marginal tax rate (when weighted by amounts of adjusted gross income). Table 4 shows that this measure of distortion falls by about 25\% from 1961 to 1965 but then doubles from 


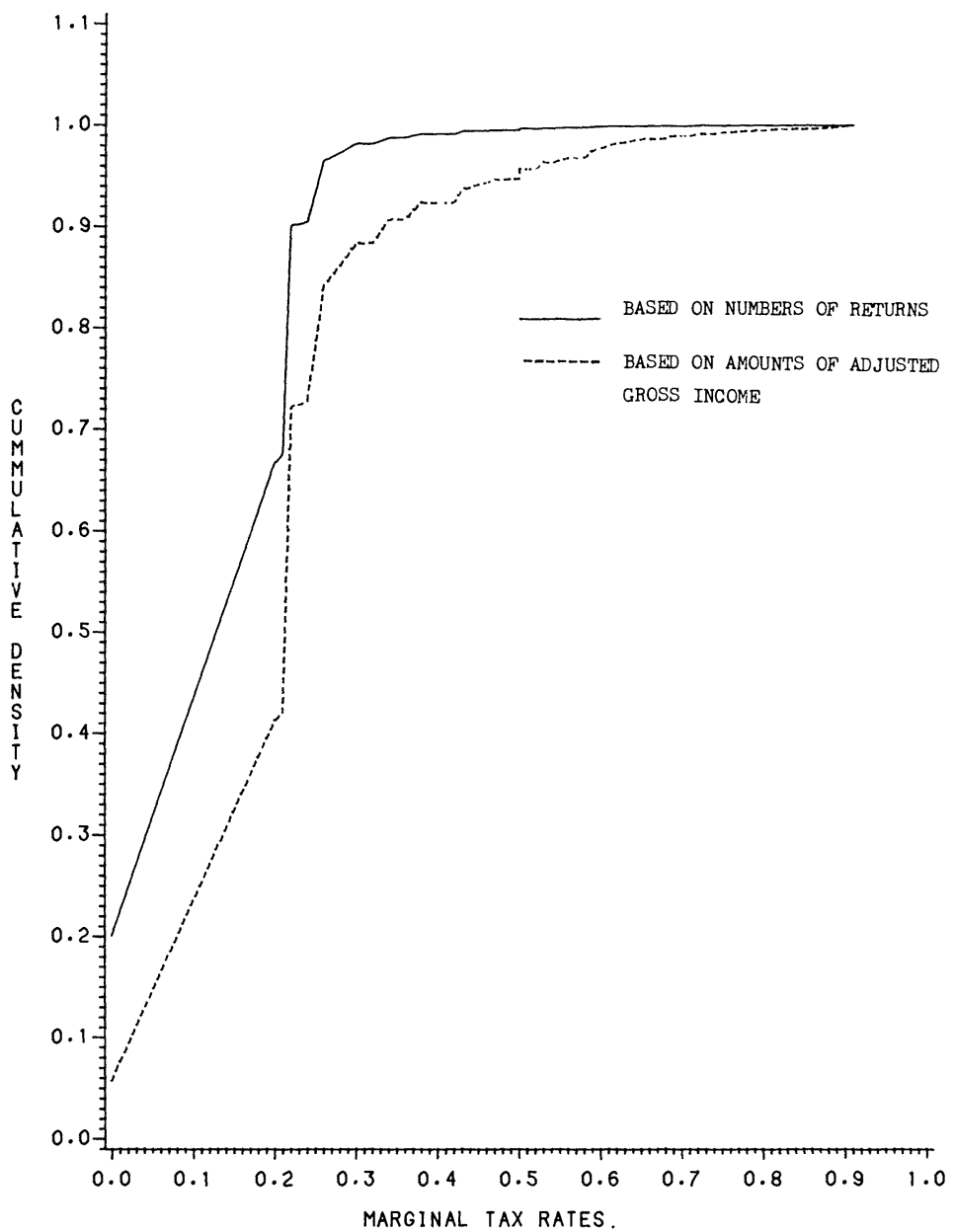

FIG. 2.-Cumulative distribution of marginal tax rates in 1961. (Note: the vertical axis shows the cumulative density, corresponding to each marginal tax rate. The data are from Statistics of Income, Individual Income Tax Returns, using the tables that classify by marginal tax rates.)

1965 to 1980 . Most of this change derives from variations in the average marginal tax rates rather than from shifts in the standard deviations.

We get a more interesting picture of dispersion when we look at the fraction of incomes or returns for which the marginal tax rates are "high" - that is, if we look at the weight in the upper tail of the cumulative densities that appear in figures 2-6. This exercise is interesting because some types of tax-avoiding activities-such as exotic tax shelters and the heavy use of currency for transactions-may become 


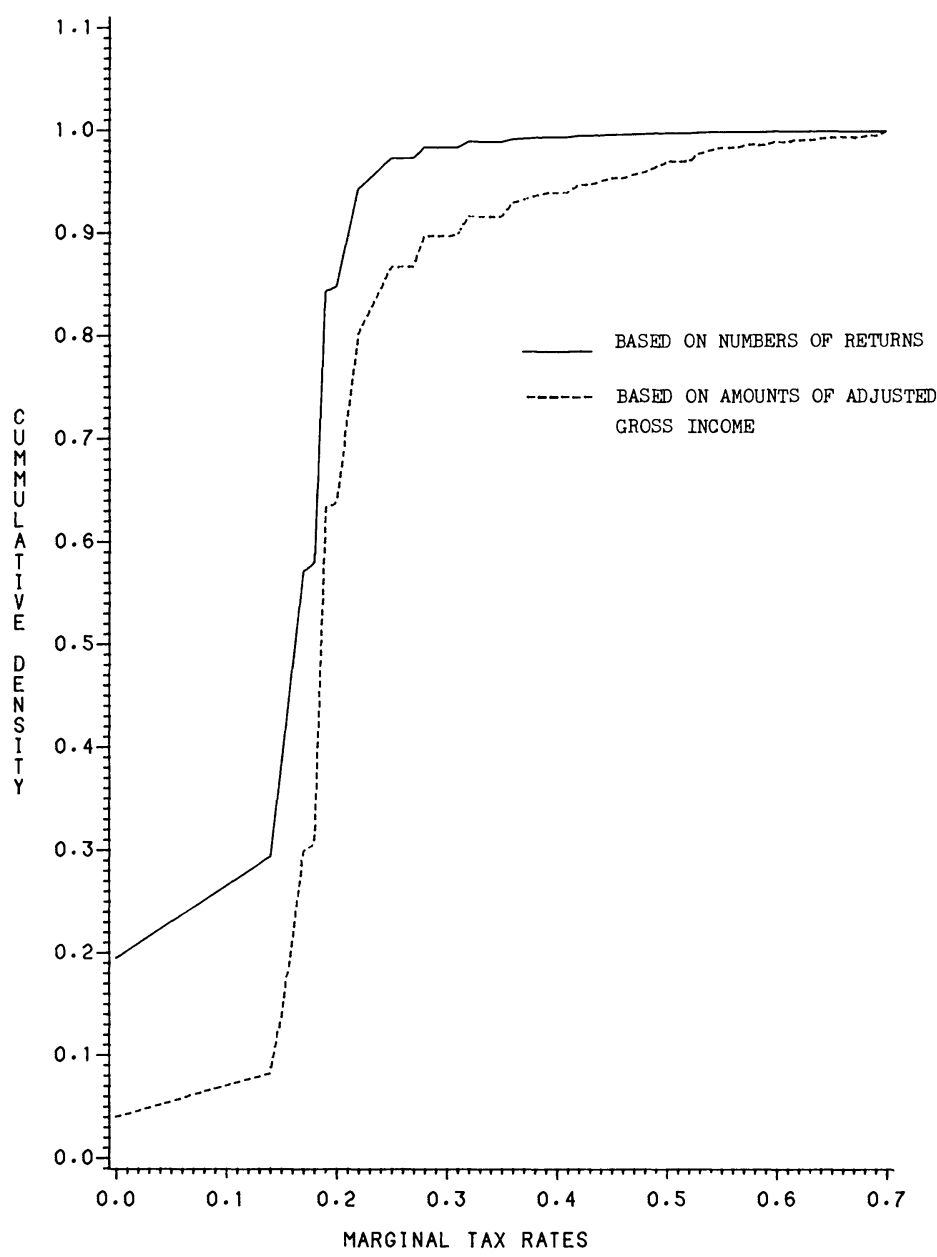

Fig. 3.-Cumulative distribution of marginal tax rates in 1965. (Note: The vertical axis shows the cumulative density, corresponding to each marginal tax rate. The data are from Statistics of Income, Individual Income Tax Returns, using the tables that classify by marginal tax rates.)

worthwhile only at very high marginal tax rates. Then, in order to study these types of phenomena, we would be more interested in the weight in the upper tail of the marginal tax rate distribution rather than in the mean or standard deviation per se.

Picking $35 \%$ arbitrarily as a high marginal tax rate, we see from table 4 that there have been dramatic increases in the fraction of adjusted gross income or of numbers of returns for which the marginal tax rate exceeds this number. Specifically, the fraction of adjusted gross incomes for which the marginal tax rate exceeds $35 \%$ falls from $9 \%$ in 1961 to 8\% in 1964 (because of the Kennedy-Johnson tax cuts) but then 


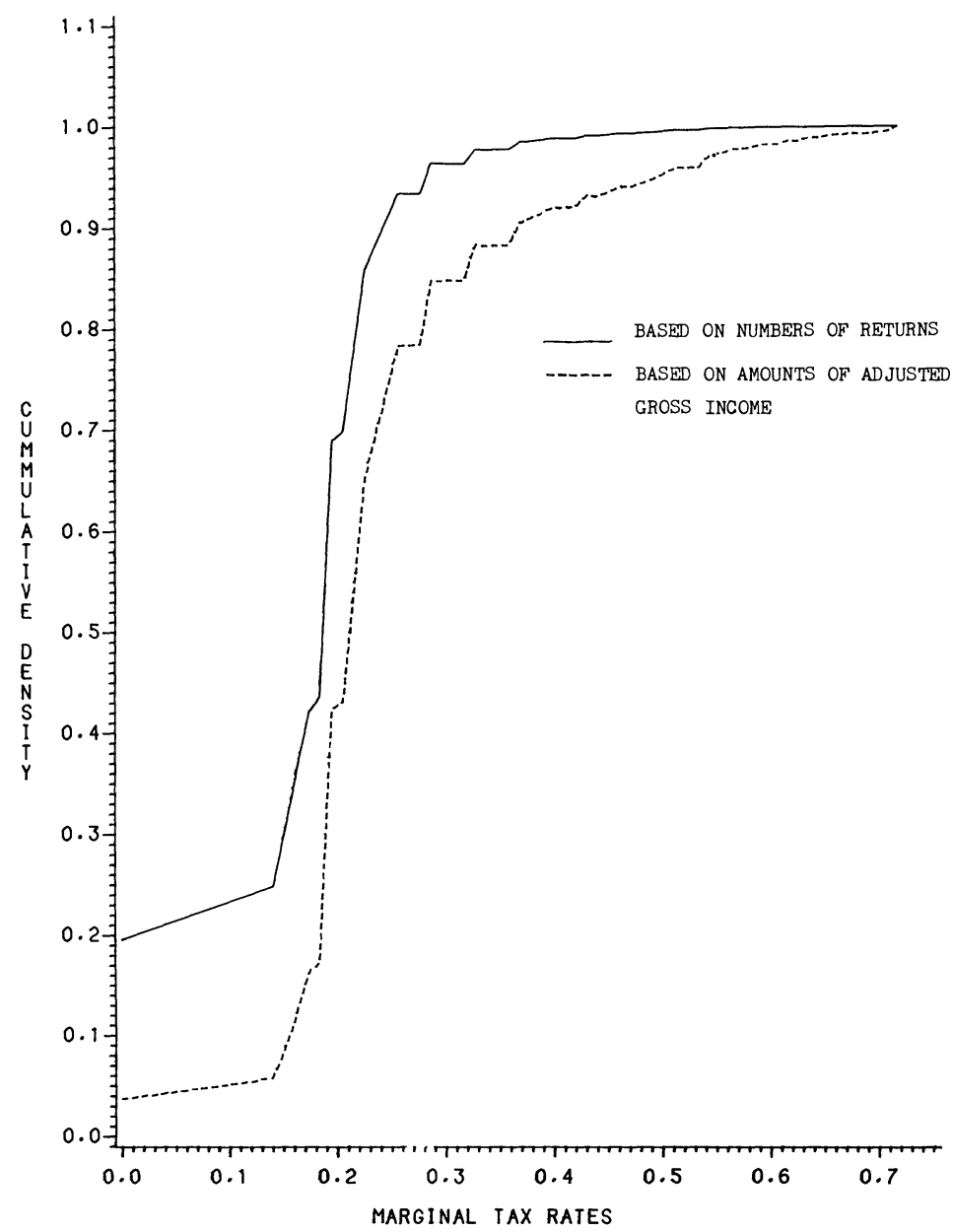

FIg. 4.-Cumulative distribution of marginal tax rates in 1970. (Note: The vertical axis shows the cumulative density, corresponding to each marginal tax rate. The data are from Statistics of Income, Individual Income Tax Returns, using the tables that classify by marginal tax rates.)

rises to $12 \%$ in $1970,18 \%$ in 1975 , and $31 \%$ in 1980 . In other words, the fraction of income that faces a marginal tax rate of at least $35 \%$ quadruples from 1964 to 1980 ! With respect to numbers of returns, the fraction falls from $1.2 \%$ in 1961 to $1.0 \%$ in 1964 but then increases to $2.2 \%$ in $1970,4.1 \%$ in 1975 , and $10.1 \%$ in 1980 . Hence, the fraction of returns that faces these high marginal tax rates rises by a factor of 10 from 1964 to 1980 .

Robert Hall has suggested (in private conversation) that the rapid rise in $\$ 100$ bills in recent years may relate to the sharp increase in the fraction of income that faces high marginal tax rates. (Others have 


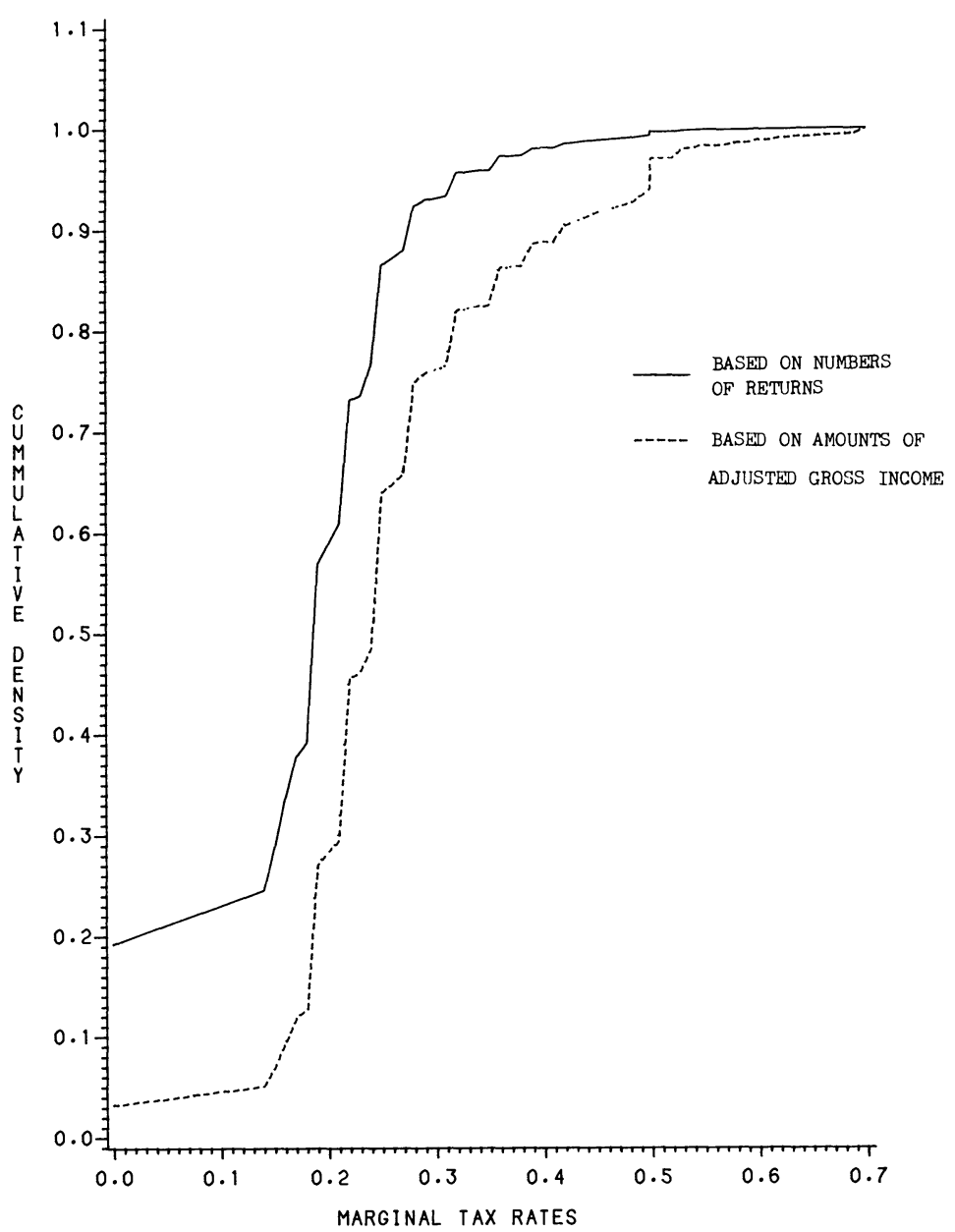

FIG. 5.-Cumulative distribution of marginal tax rates in 1975. (Note: The vertical axis shows the cumulative density, corresponding to each marginal tax rate. The data are from Statistics of Income, Individual Income Tax Returns, using the tables that classify by marginal tax rates.)

suggested the growth in criminal activity as a cause.) In particular, the fraction of the value of all currency that is in denominations of $\$ 100$ or greater is highly stable-varying only between $20 \%$ and $22 \%$-from 1944 to $1970 .{ }^{19}$ But the fraction then increases sharply to reach $36 \%$ for July 1980 and 39\% for July 1982.

19. This behavior is surprising, given the large increase in prices and real incomes. For some reason, the average denomination of currency outstanding (total dollar value divided by total number of bills) does not change much over this period. The sources for our data on currency denominations are the Board of Governors of the Federal Reserve System, Banking and Monetary Statistics, p. 415; Banking and Monetary Statistics, 


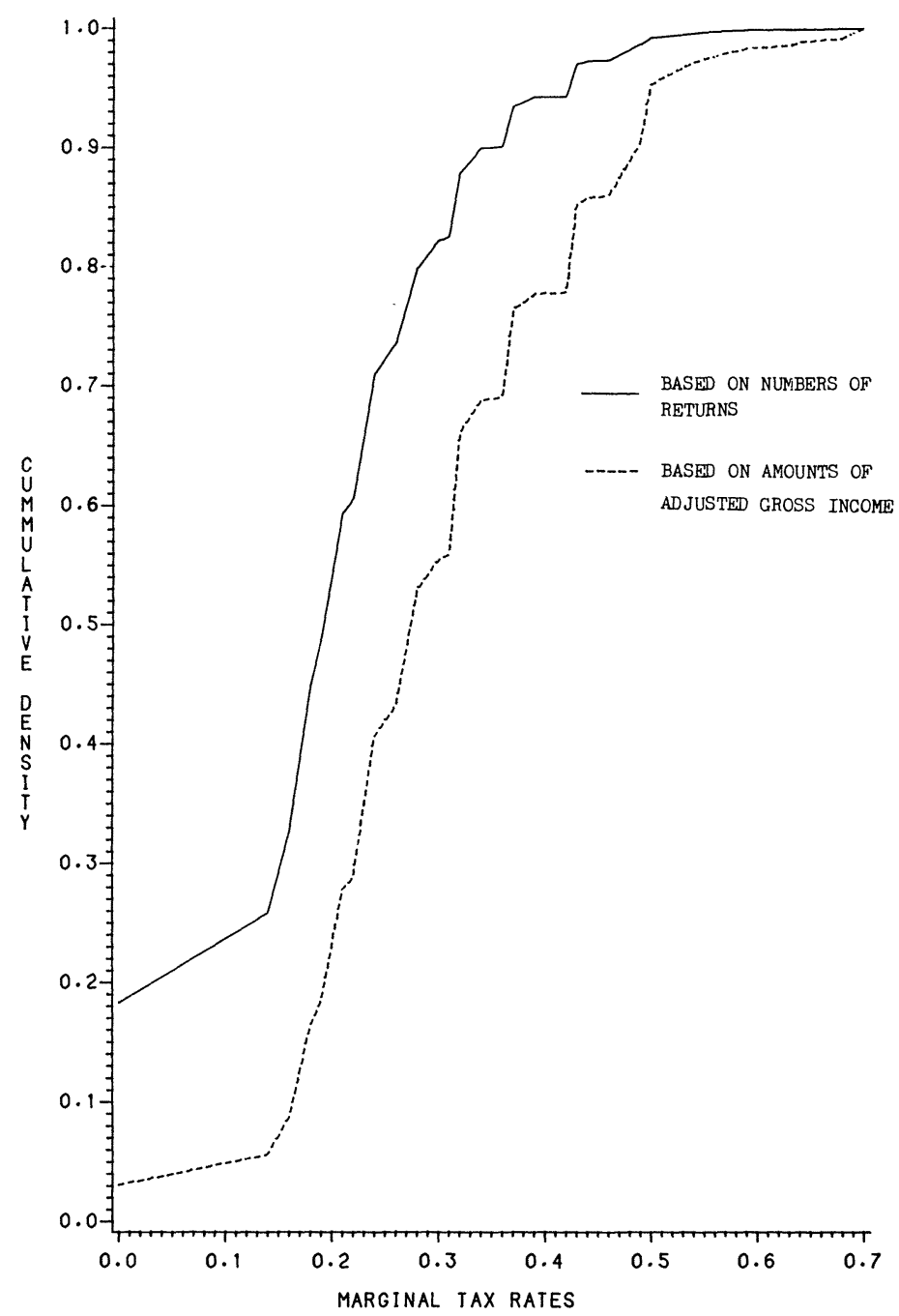

FIG. 6.-Cumulative distribution of marginal tax rates in 1980. (Note: The vertical axis shows the cumulative density, corresponding to each marginal tax rate. The data are from Statistics of Income Bulletin, December 1982, using the tables that classify by marginal tax rates.)

\section{The Behavior of Deductions}

Figures 7-11 show the cross-sectional relation of deductions per return to adjusted gross income per return (for all filing statuses) for the years $1961,1965,1970,1975$, and 1980. Recall that our concept of deduc-

1941-1970, pp. 622 ff.; Annual Statistical Digest, 1970-1979, p. 552; and U.S. Department of the Treasury, Monthly Statement of U.S. Currency and Coin, Form 1028, various issues. 


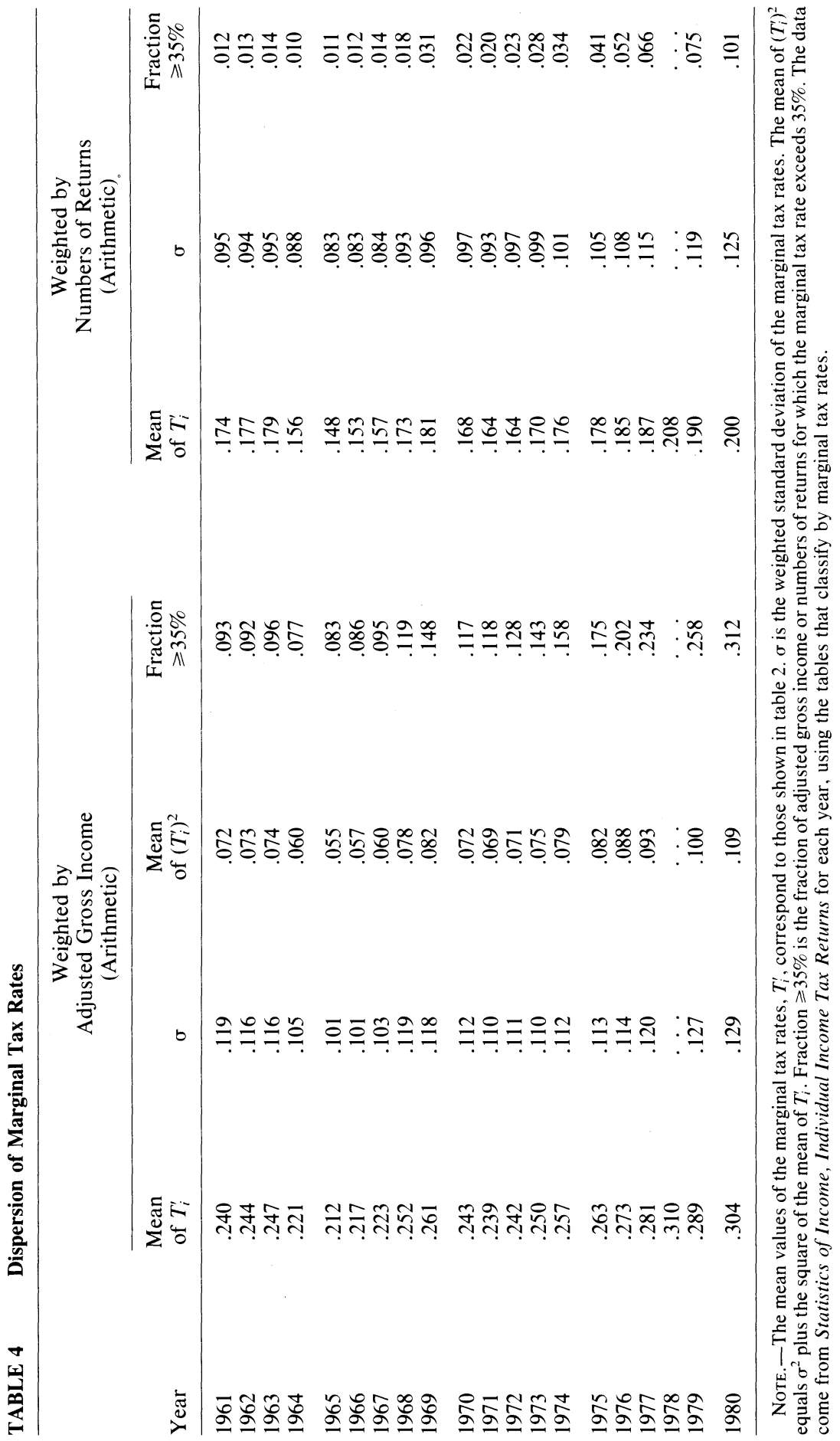




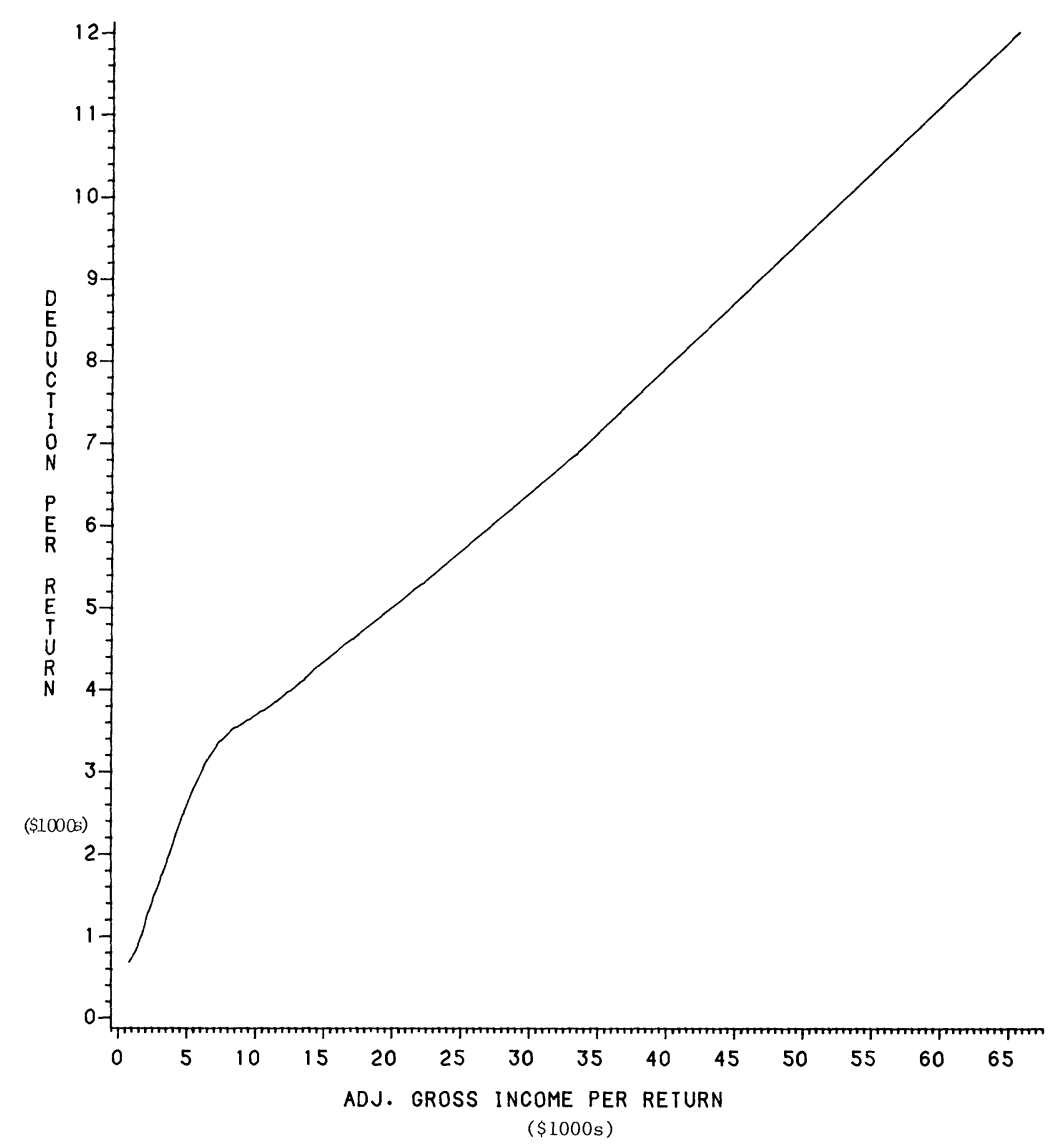

Fig. 7.-Deductions per return vs. adjusted gross income per return in 1961. (Note: The data are from Statistics of Income, Individual Income Tax Returns, using the tables that classify by adjusted gross income per return.)

tions, which refers to the difference between adjusted gross and taxable income, includes exemptions but excludes the various subtractions from total income that precede the calculation of adjusted gross income. The figures consider the range of adjusted gross income per return up to $\$ 70,000$.

The data do not suggest much tendency for the slope $d D / d Y$ to change with income once adjusted gross income exceeds a fairly low amount, which is $\$ 5,000-\$ 10,000$ between 1961 and $1980 .^{20}$ In fact, this appearance of a roughly linear relation between deductions and ad-

20. If we look only at itemized deductions (excluding standard deductions and exemptions), then the slope increases at the low end of incomes. But the relation between itemized deductions per return and adjusted gross income per return is again roughly linear for values of adjusted gross income that exceed $\$ 5,000-\$ 10,000$. 


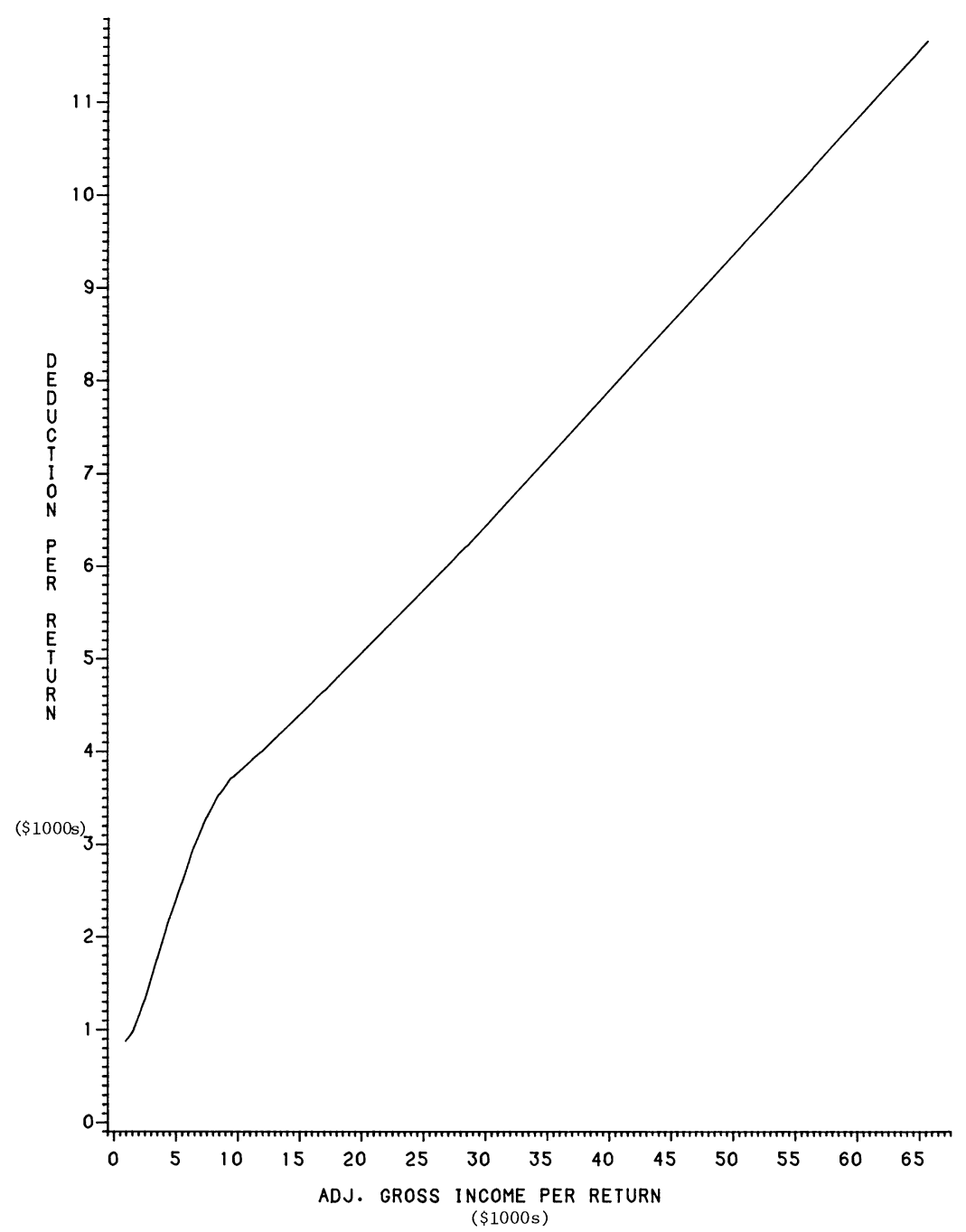

FIG. 8.-Deductions per return vs. adjusted gross income per return in 1965. (Note: The data are from Statistics of Income, Individual Income Tax Returns, using the tables that classify by adjusted gross income per return.)

justed gross income holds up if we add the upper tail of income. (At the low end, the slope decreases with adjusted gross income.) For the years shown in the figures, which range from 1961 to 1980 , and for values of adjusted gross income that exceed $\$ 10,000$, the estimated slopes $d D / d Y$ are in the interval between .16 and .18 . That is, once adjusted gross income is greater than $\$ 5,000-\$ 10,000$, deductions per return are roughly a positive intercept plus $16 \%-18 \%$ of adjusted gross 


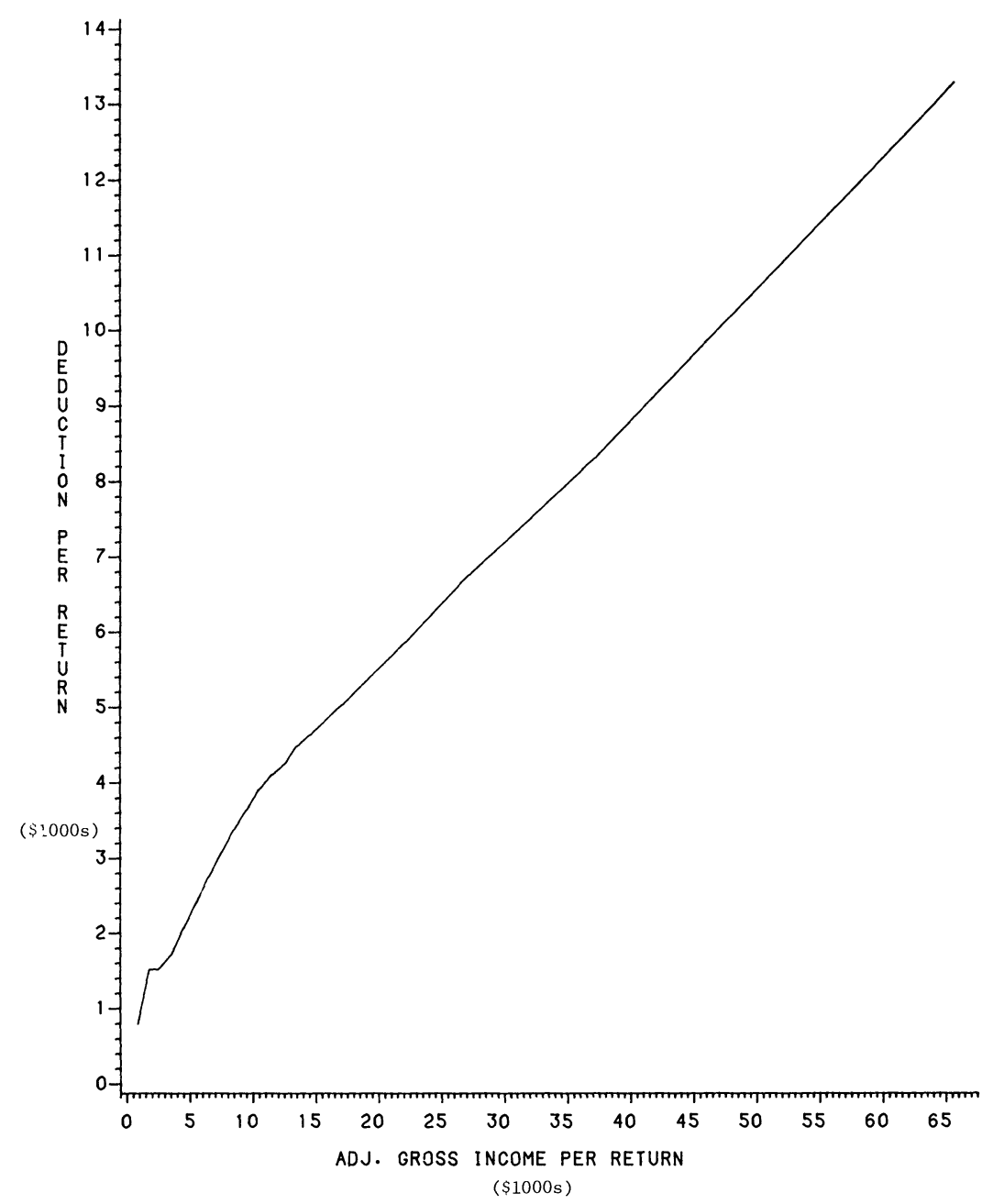

FIG. 9.-Deductions per return vs. adjusted gross income per return in 1970. (Note: The data are from Statistics of Income, Individual Income Tax Returns, using the tables that classify by adjusted gross income per return.)

income per return. (Of course, we cannot say how adjusted gross income per return relates to total income per return-presumably most of the serious tax avoidance precedes the calculation of adjusted gross income.)

Recall that the marginal relation of taxes to income is $d T / d Y=$ $T^{\prime}(1-d D / d Y)$. Therefore, if $d D / d Y$ is roughly constant-as appears to be true if we measure $Y$ by adjusted gross income-then $d T / d Y$ is approximately a constant fraction of the marginal tax rate, $T^{\prime}$. In par- 


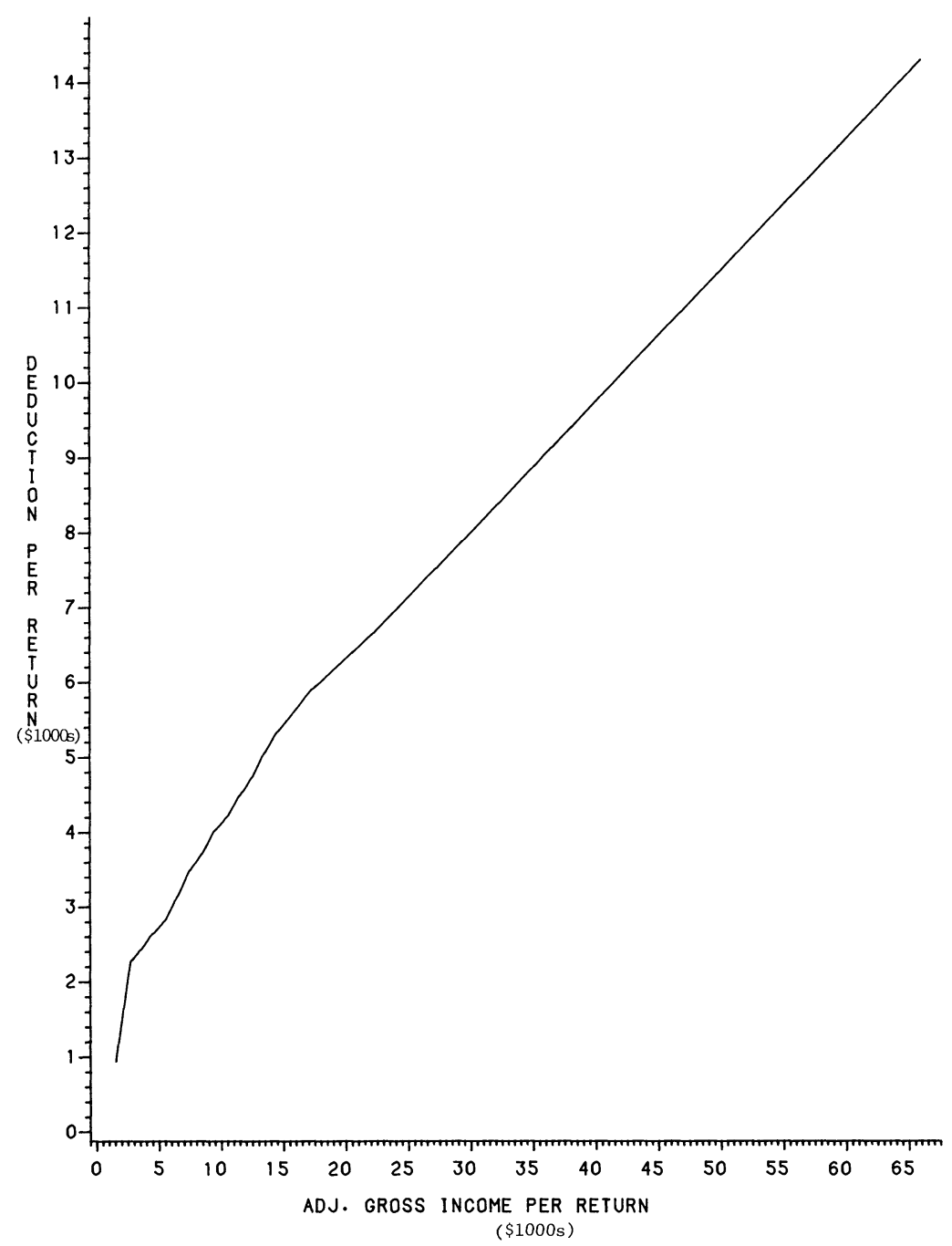

FIG. 10.-Deductions per return vs. adjusted gross income per return in 1975. (Note: The data are from Statistics of Income, Individual Income Tax Returns, using the tables that classify by adjusted gross income per return.)

ticular, if $d D / d Y$ lies between .16 and .18 , then $d T / d Y$ is $82 \%-84 \%$ of $T^{\prime}$. In fact, for the post-World War II period, this relation accounts for most of the difference in average levels between Joines's estimates of $d T / d Y$ (see table 3 ) and our figures on average marginal tax rates. For $1970-75$, his values average $86 \%$ of ours, while for $1946-75$ they are $81 \%$ of ours. 


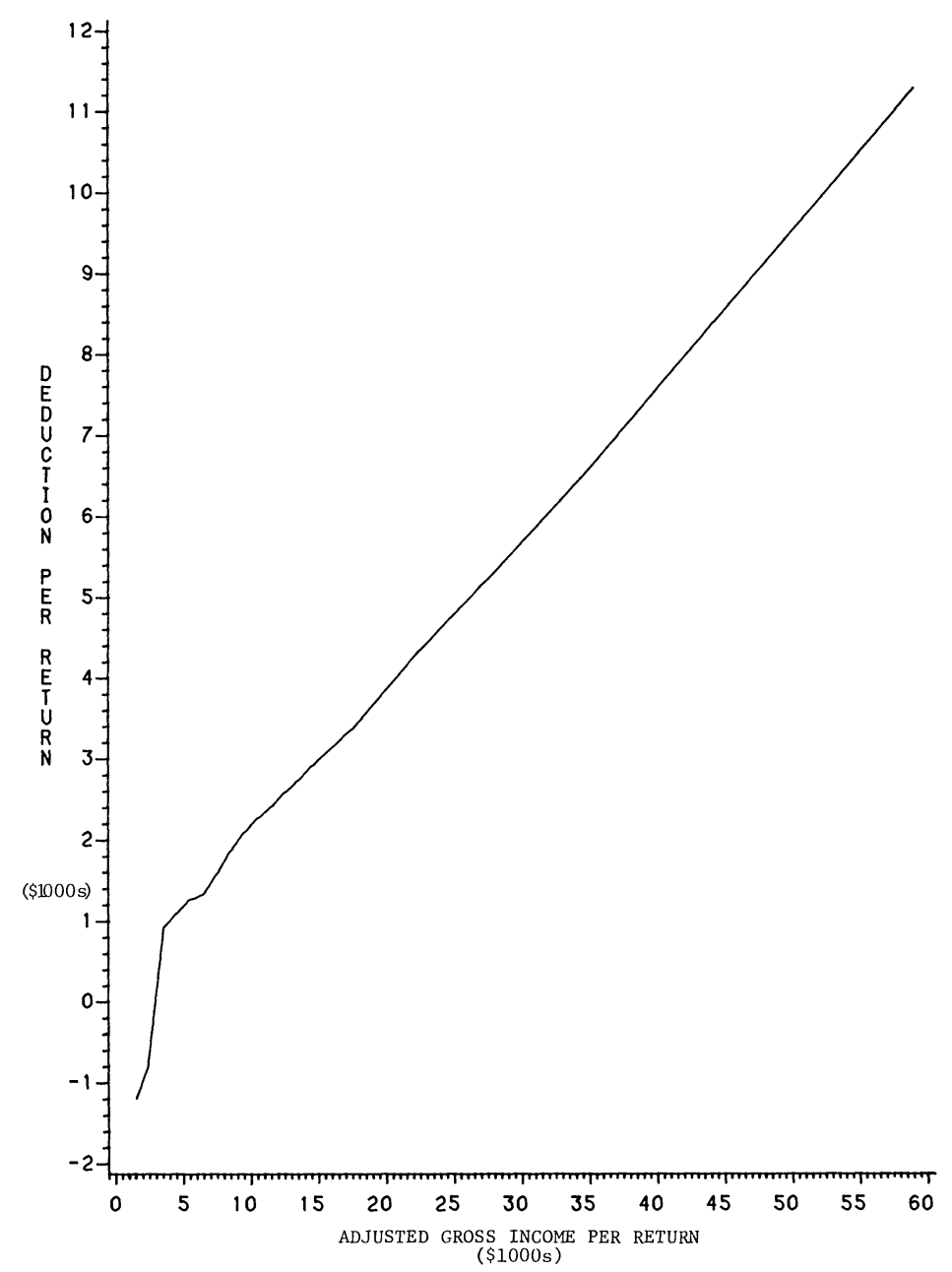

Fig. 11.-Deductions per return vs. adjusted gross income per return in 1980. (Note: The data are from Statistics of Income, Individual Income Tax Returns, using the tables that classify by adjusted gross income per return.)

\section{Concluding Remarks}

Our time series on average marginal tax rates should be useful for a variety of research purposes. But our own plans-and our initial motivation for constructing the series-focus on two areas. First, we plan to use the data on average marginal tax rates in a study of the effects of government policies on aggregate output, employment, and so on. Some previous work on this topic stresses the influences of monetary disturbances and of various types of government purchases. (See, e.g., 
Barro 1981.) Now we can add a measure of the average marginal tax rate to assess this aspect of fiscal policy. Conceivably we may also be able to distinguish temporary changes in marginal tax rates from permanent ones. Then, the temporary changes involve intertemporal substitution effects, which do not arise for the permanent changes. Hence we can test for a different impact of temporary versus permanent shifts in marginal tax rates on output, employment, and other macroeconomic variables.

Second, a theory of public debt creation, outlined in Barro (1979), includes the intertemporal behavior of tax rates. Specifically, this theory suggests that debt management smooths tax rates over time, in spite of fluctuations in government spending and aggregate real income. In order to test this theory fully, we need the time-series data on average marginal tax rates.

Finally, as mentioned before, the present series on average marginal tax rates is incomplete because it refers only to the federal individual income tax. We plan some extensions, at least to incorporate the social security tax and some other levies. At this point, we are uncertain about how far we can go in constructing a comprehensive measure of the average marginal tax rate.

\section{Appendix}

Table A1 shows estimates of average marginal tax rates for 1944-78, based on the tables that classify by ranges of adjusted gross income per return. We indicated in the text our procedure for estimating the marginal tax rate within each class. Then we weight either by adjusted gross income or by numbers of returns and use either the arithmetic or geometric formula to generate the figures shown in the table.

We use the values in table A1 to fill in our missing data as follows. For the cases where we weight by adjusted gross income, we get the arithmetic values for 1944-60 from the equation $-.021+1.093$ - (value from table A1). The coefficients come from a regression of the values shown in table 2 on those shown in table A1 over the period 1961-70. For the geometric form, we use the equation $-.020+1.071 \cdot\left(\right.$ value from table A1). In both cases the $R^{2}$ values for the regressions are nearly .99. For 1978, we get the arithmetic value from the equation $-.019+1.112 \cdot$ (value from table A1). These coefficients come from a regression over the period 1971-77. Similarly, for the geometric value, we use the equation $-.005+1.045 \cdot$ (value from table A1). In these cases the values of $R^{2}$ are .98 .

We use an analogous procedure for the cases where we weight by numbers of returns. Here we get the missing data for 1944-53 by using regression equations that are estimated over the period 1954-70. For the arithmetic case the equation is $-.004+1.034 \cdot$ (value from table A1). For the geometric case the equation is $-.004+1.037 \cdot$ (value from table A1). In these cases the $R^{2}$ values exceed .99. We get the missing data for 1978 from regressions that are estimated over the period $1971-77$. For the arithmetic case the equation is 
TABLE A1 Estimates of Average Marginal Tax Rates for 1944-78

\begin{tabular}{|c|c|c|c|c|}
\hline \multirow[b]{2}{*}{ Year } & \multicolumn{2}{|c|}{$\begin{array}{c}\text { Weighted by } \\
\text { Adjusted Gross Income }\end{array}$} & \multicolumn{2}{|c|}{$\begin{array}{l}\text { Weighted by } \\
\text { Numbers of Returns }\end{array}$} \\
\hline & Arithmetic & Geometric & Arithmetic & Geometric \\
\hline 1944 & .250 & .278 & .192 & .198 \\
\hline $\begin{array}{l}1945 \\
1946 \\
1947 \\
1948 \\
1949\end{array}$ & $\begin{array}{l}.254 \\
.226 \\
.226 \\
.184 \\
.180\end{array}$ & $\begin{array}{l}.285 \\
.252 \\
.249 \\
.198 \\
.193\end{array}$ & $\begin{array}{l}.192 \\
.140 \\
.151 \\
.121 \\
.118\end{array}$ & $\begin{array}{l}.198 \\
.146 \\
.157 \\
.125 \\
.122\end{array}$ \\
\hline $\begin{array}{l}1950 \\
1951 \\
1952 \\
1953 \\
1954\end{array}$ & $\begin{array}{l}.198 \\
.231 \\
.249 \\
.247 \\
.222\end{array}$ & $\begin{array}{l}.216 \\
.252 \\
.269 \\
.265 \\
.239\end{array}$ & $\begin{array}{l}.130 \\
.163 \\
.179 \\
.181 \\
.158\end{array}$ & $\begin{array}{l}.135 \\
.168 \\
.185 \\
.187 \\
.163\end{array}$ \\
\hline $\begin{array}{l}1955 \\
1956 \\
1957 \\
1958 \\
1959\end{array}$ & $\begin{array}{l}.228 \\
.231 \\
.232 \\
.229 \\
.236\end{array}$ & $\begin{array}{l}.246 \\
.249 \\
.249 \\
.245 \\
.253\end{array}$ & $\begin{array}{l}.162 \\
.166 \\
.167 \\
.164 \\
.169\end{array}$ & $\begin{array}{l}.167 \\
.171 \\
.173 \\
.170 \\
.174\end{array}$ \\
\hline $\begin{array}{l}1960 \\
1961 \\
1962 \\
1963 \\
1964\end{array}$ & $\begin{array}{l}.234 \\
.239 \\
.240 \\
.243 \\
.222\end{array}$ & $\begin{array}{l}.250 \\
.257 \\
.257 \\
.260 \\
.234\end{array}$ & $\begin{array}{l}.169 \\
.171 \\
.174 \\
.176 \\
.154\end{array}$ & $\begin{array}{l}.175 \\
.176 \\
.179 \\
.181 \\
.159\end{array}$ \\
\hline $\begin{array}{l}1965 \\
1966 \\
1967 \\
1968 \\
1969\end{array}$ & $\begin{array}{l}.214 \\
.219 \\
.226 \\
.251 \\
.261\end{array}$ & $\begin{array}{l}.225 \\
.230 \\
.238 \\
.266 \\
.276\end{array}$ & $\begin{array}{l}.147 \\
.152 \\
.156 \\
.171 \\
.180\end{array}$ & $\begin{array}{l}.151 \\
.156 \\
.160 \\
.176 \\
.186\end{array}$ \\
\hline $\begin{array}{l}1970 \\
1971 \\
1972 \\
1973 \\
1974\end{array}$ & $\begin{array}{l}.240 \\
.231 \\
.235 \\
.243 \\
.252\end{array}$ & $\begin{array}{l}.252 \\
.242 \\
.246 \\
.254 \\
.264\end{array}$ & $\begin{array}{l}.166 \\
.161 \\
.160 \\
.166 \\
.173\end{array}$ & $\begin{array}{l}.172 \\
.166 \\
.166 \\
.172 \\
.179\end{array}$ \\
\hline $\begin{array}{l}1975 \\
1976 \\
1977 \\
1978\end{array}$ & $\begin{array}{l}.253 \\
.263 \\
.269 \\
.295\end{array}$ & $\begin{array}{l}.265 \\
.276 \\
.283 \\
.310\end{array}$ & $\begin{array}{l}.167 \\
.176 \\
.175 \\
.193\end{array}$ & $\begin{array}{l}.175 \\
.184 \\
.183 \\
.203\end{array}$ \\
\hline
\end{tabular}

NoTE. - The data are from Statistics of Income, Individual Income Tax Returns for each year, using the tables that classify by adjusted gross income per return. See the notes to table 2 in the text.

$-.054+1.361 \cdot$ (value from table A1). For the geometric case the equation is $-.050+1.323 \cdot$ (value from table A1). Here the $R^{2}$ values are .88 and .93 , respectively.

\section{Referencès}

Barro, R. J. 1979. On the determination of the public debt. Journal of Political Economy 87 (October): 940-71. 
Barro, R. J. 1981. Output effects of government purchases. Journal of Political Economy 89 (December): 1086-1121.

Gordon, R. H. 1982. Social security and labor supply incentives. National Bureau of Economic Research Working Paper no. 986, September.

Heckman, J. J. 1983. Comment. In Feldstein (ed.), Behavioral Simulation Methods in Tax Policy Analysis. Chicago: University of Chicago Press (for National Bureau of Economic Research).

Joines, D. H. 1981. Estimates of effective marginal tax rates on factor incomes. Journal of Business 54 (April): 191-226.

$\rightarrow$ Miller, M. H., and Scholes, M. S. 1978. Dividends and taxes. Journal of Financial Economics 6 (December): 333-64.

O'Neill, D. M. 1982. The underground economy. Washington, D.C.: U.S. Department of Commerce, Bureau of the Census, March.

Protopapadakis, A. 1982. Some indirect evidence on effective capital gains tax rates. Unpublished, University of Pennsylvania, July.

$\rightarrow$ Seater, J. 1982. Marginal federal personal and corporate income tax rates in the U.S., 1909-1975. Journal of Monetary Economics 10 (November 1982): 361-81.

Sunley, E. M. 1974. The maximum tax on earned income. National Tax Journal 27 (December): 543-52.

U.S. Department of the Treasury, Internal Revenue Service. Various issues. Statistics of Income, Individual Income Tax Returns.

Wright, C. 1969. Saving and the rate of interest. In A. Harberger and M. J. Bailey (eds.), The Taxation of Income from Capital. Washington, D.C.: Brookings Institution. 